PNL-2713

UC-11

\begin{abstract}
A Research Report for the
Rockwell Hanford Operations
\end{abstract}

\title{
Shrub-Inhabiting Insects of the 200 Area Plateau, Southcentral Washington
}

\section{L.E. Rogers}

October 1979

Prepared for the U.S. Depariment of Energy under Contract No. EY-76-C-06-1830

Pacific Northwest Laboratoty Operated for the U.S. Department of Energy by Battelle Memorial Institute 
NOTICE

This report was preparted as an arcouni of work sponiated by tha United Sates Government: Neither the United States nar the Department of Energy. not any of their etriployees, nor any of their contractan. vibcontractors, of their emplorees, makes any wartasty, express or implied, ar asumes any legal liability of responsibility for the accuracy, completenejs or usefulnes al any information, apparatia. product or proces disclowed, or repanients that its use woufd not inffinge privaleig bwried rights.

The viem, opinions and condunions contraites in thin hipoil ire those of the contractor and do not necesurily represent those of the Unied Soutrs Covecnment or the United Stater Deparment of Energy:

\author{
PACIEIC NORTHWEST LABORATORY \\ operated by \\ BATHIII \\ for the \\ UNITED STATES DEPARTMENT OF ENERGY \\ thder Contract EY.r.6.C.06-1630
}

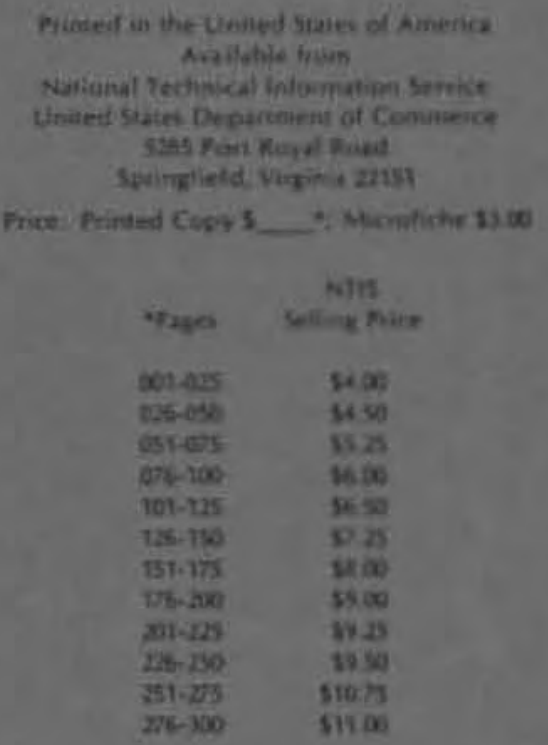




\begin{abstract}
A Research Report for the Rockwell Hanford Operations
\end{abstract}

\title{
Shrub-Inhabiting Insects of the 200 Area Plateau, Southcentral Washington
}

\author{
L.E. Rogers
}

October 1979

Prepared for

the U.S. Department of Energy

under Contract No. EY-76-C-06-1830

This research was performed as part of Rockwell Hanford Operations' Long-Term Transuranic Defense Waste Program.

Pacific Northwest Laboratory

Richland, Washington 99352 


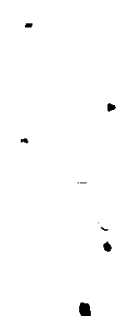

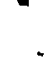




\section{EXECUTIVE SUMMARY}

This study characterizes the insects (including spiders) associated with major shrubs of the 200 Area plateau on the Hanford Site in southcentral Washington. Big sagebrush (Artemisia tridentata), rabbitbrush (Chrysothamnus sp.) and hopsage (Grayia spinosa) were the three shrubs included in the study. Hemiptera (true bugs) and homoptera (bugs) were the two groups most abundant on sagebrush. Homoptera and Araneida (spiders) were the common inhabitants of rabbitbrush, and Orthoptera (grasshoppers), Coleoptera (beetles) and Araneida the taxa most frequently collected from hopsage. A discussion of the effects of insects on western native shrubs is included. None of the insect populations appeared to threaten the stability of shrub stands, which is important because of the erodability of 200 Area soils. 


\section{ACKNOWLEDGMENTS}

Th is study for the Department of Energy (DOE) was produced for the Rockwe 11 Hanford Operations under intercontractor support agreements as part of the Long-Term Transuranic Defence Waste program. Sampling methods, reference materials and the development of professional staff were funded by the DOE Office of Health and Environmental Research (formerly Department of Biomedical and Environmental Research). The author thanks Norman Wood ley of Harvard University and Joe Sheldon of Eastern Baptist College for assistance in data collection and analysis. 
CONTENTS

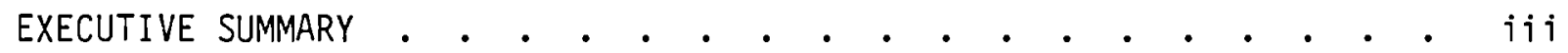

ACKNOWLEDGMENTS . . . . . . . . . . . . . . . . . . . . . . iv

LIST OF TABLES . . . . . . . . . . . . . . . . . . . . .

LIST OF FIGURES . . . . . . . . . . . . . . . . . . . vi

INTRODUCTION . . . . . . . . . . . . . . . . . . . . 1

SITE DESCRIPTION . . . . . . . . . . . . . . . . 3

METHODS . . . . . . . . . . . . . . . . . . . . . 5

RESULTS • . . . . . . . . . . . . . . . . . . . . 7

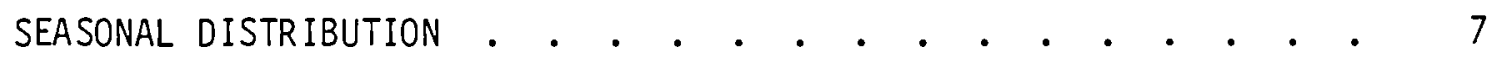

INSECT TAXA ASSOCIATED WITH RABBITBRUSH . . . . . . . . . 7

INSECT TAXA ASSOCIATED WITH HOPSAGE. • . . . . . . . . . . . 10

INSECT TAXA ASSOCIATED WITH SAGEBRUSH . . . . . . . . . . . 10

COMPARISON OF SHRUB INVERTEBRATE FAUNA . . . . . . . . . 14

DISCUSSION. . . . . . . . . . . . . . . . . . . . . . . 17

SAGEBRUSH . . . . . . . . . . . . . . . . . . 17

Aroga websteri . . . . . . . . . . . . . 17

Leaf Beetles . . . . . . . . . . . . . 17

Grasshoppers . . . . . . . . . . . . . . . . 17

Darkling Beetles. . . . . . . . . . . . . 18

Galls . . . . . . . . . . . . . . 18

RABBITBRUSH . . . . . . . . . . . . . . . 18

HOPSAGE . . . . . . . . . . . . . . . . . . 18

REFERENCES. . . . • . . . . . . . . . . . . . . . . 19

APPENDIX A - SHRUB-INHABITING INSECT DATA . . . . . . . . . . A. 1 


\section{$\underline{\text { TABLES }}$}

1 Relative Abundance (\%) of Major Insect Taxa Collected from Rabbitbrush at the B-C Cribs Site During 1974 and 1975 . . . . . 9

2 Homoptera Families Collected from Rabbitbrush Samples . . . • $\quad$ • 9

3 Relative Abundance (\%) of Major Insect Taxa Collected from Hopsage During 1974 and 1975 at the Control Site . . . . . . 11

4 Relative Abundance (\%) of Major Insect Taxa Collected from Big Sagebrush During 1974 and 1975 at the B-C Cribs Site . . . . 11

5 Relative Abundance (\%) of Major Insect Taxa Collected from Big Sagebrush During 1974 and 1975 at the Redox Site . . . . . 12

6 Relative Abundance (\%) of Major Insect Taxa Collected from Big Sagebrush During 1974 and 1975 at the Control Site . . . . 12

7 Insect Taxa Rankings Collected from Big Sagebrush on B-C Cribs, Redox Pond and Control Study Areas . . . . . . . . . . 13

8 Hemiptera Families Collected from Big Sagebrush . . • . • . . 13

9 Homoptera Families Associated with Sagebrush . . . . . . . . 14

10 Relative Abundance of Insect Taxa Collected from Sagebrush, Rabbitbrush and Hopsage . . . . . . . . . . . . . . 15

11 Insect Taxa Rankings from Sagebrush, Rabbitbrush and Hopsage . • . 15

\section{FIGURES}

1 The Department of Energy's Hanford Site in Southcentral

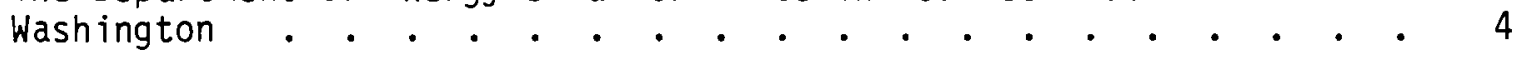

2 Shrub Insect Field Data Sheet . . • . . . . . . . . . . 6

3 Seasonal Distribution of Insect Abundance on Sagebrush . . . . 8

4 Seasonal Distribution of Insect Abundance on Hopsage and Rabbitbrush 


\section{SHRUB-INHABITING INSECTS OF THE 200 AREA PLATEAU, SOUTHCENTRAL WASHINGTON}

\section{$\underline{\text { INTRODUCTION }}$}

This study was designed to characterize the insects inhabiting the major shrubs of the 200 Area plateau. The objectives of the study were to describe the taxonomic composition, seasonal abundance and general feeding habits of major insect groups. The data presented here are particularly intended for use in nuclear waste management studies.

Characterization studies describing the ecology of the 200 Area plateau have received special attention during the past few years. These studies have been designed to provide an understanding of the biota present in the 200 Area ecosystem, their food habits, and their responses to both natural and maninduced perturbations.

This document describes the types, seasonal abundance and general feeding habits of insect taxa (including spiders) inhabiting the major shrubs of the 200 Area plateau. Past documents concerning 200 Area insects include an analys is of grasshopper populations (Sheldon and Rogers, 1978) and darkling beetle populations (Rogers et al., 1978). Also recently documented (Rogers and Rickard, 1977) is an analys is of the 200 Area ecosystem and a description of the kinds of environmental studies needed to provide an adequate data base for future waste management needs.

Taxonomic composition is primarily described at family and order leveis, since this provides sufficient detail for most management applications. Some discussion is included at the specific level where particular species are considered especially important to the waste management objectives. 


\section{.}




\section{SITE DESCRIPTION}

Three study areas on the Department of Energy's Hanford Site were selected for collection of shrub-inhabiting insects: 1) near the B-C Cribs area, 2) near the former Redox Pond area, and 3) a control area located on the nearby Arid Lands Ecology (ALE) Reserve. The ir locations are shown in Figure 1.

Sagebrush/Sandberg bluegrass (Artemisia tridentata/Poa sandbergii) communities dominate a 11 three study locations. Cheatgrass (Bromus tectorum) is abundant in the open areas between shrubs. Past agricultural endeavors probably account for the abundance of cheatgrass and other alien plants at these low elevation study areas at the Hanford Site. Cline et al. (1975) describe the vegetation of these areas more completely. Precipitation in the study areas averages about $15 \mathrm{~cm} / \mathrm{yr}$ (Stone et al., 1972). 


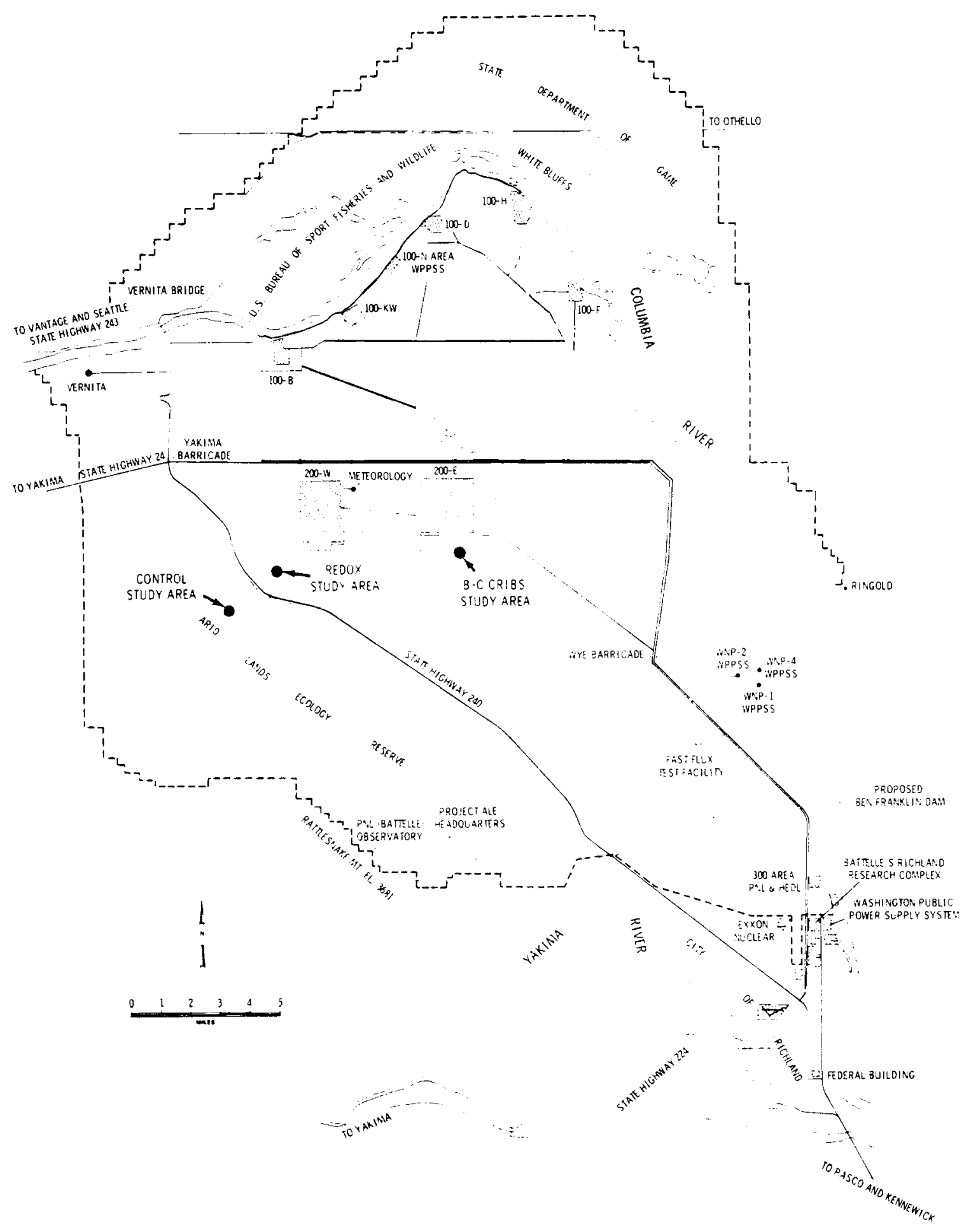

FIGURE 1. The Department of Energy's Hanford Site in Southcentral Washington 


\section{METHODS}

Insects inhabiting big sagebrush (Artemisia tridentata), hopsage (Grayia spinosa), and rabbitbrush (Chrysothamnus sp.) shrubs were collected using a standard sweep net. Big sagebrush was sampled on all three study sites, but rabbitbrush was only sampled on the B-C Cribs area, and hopsage only on the control area. Hopsage and rabbitbrush plants were not abundant at the other study locations. Each sample collection consisted of 100 sweeps from each shrub species. The collected materials (insects, leaves, etc.) were placed in a killing jar for a few minutes and then transferred to collection jars individually marked with the date, host plant, and location of capture. All collection jars were then transported to the laboratory where the material was sorted and all specimens posted to a key punch form (Figure 2). Representative taxa were retained where identifications were uncertain. These specimens were forwarded to specialists for positive identification. Spiders (Araneida) were also included in the analys is even though they are not members of the class Insecta.

The statistic selected for comparing insect taxa inhabiting study shrubs in different areas or different shrub species was the Spearman rank correlation coefficient: $r_{s}$. This is one of the best known and earliest statistics based on ranks developed. The value of $r_{S}$ may be established according to the formula:

$$
r_{s}=1-\frac{6 \sum_{i=i^{2}}^{N}{ }^{2}}{N^{3}-N}
$$

where $d_{j}=$ the difference between rankings for a particular comparison and $N=$ the sample size.

When $N$ is large $(>10)$ the significance of a calculated $r_{S}$ can be obtained from

$$
t=r_{s} \frac{n-2}{\sqrt{1-r_{s}^{2}}}
$$

Distribution values are also available from table values. For more detailed information concerning the use of the Spearman rank correlation coefficient, see Dixon and Massey (1969) or Siegel (1956). 


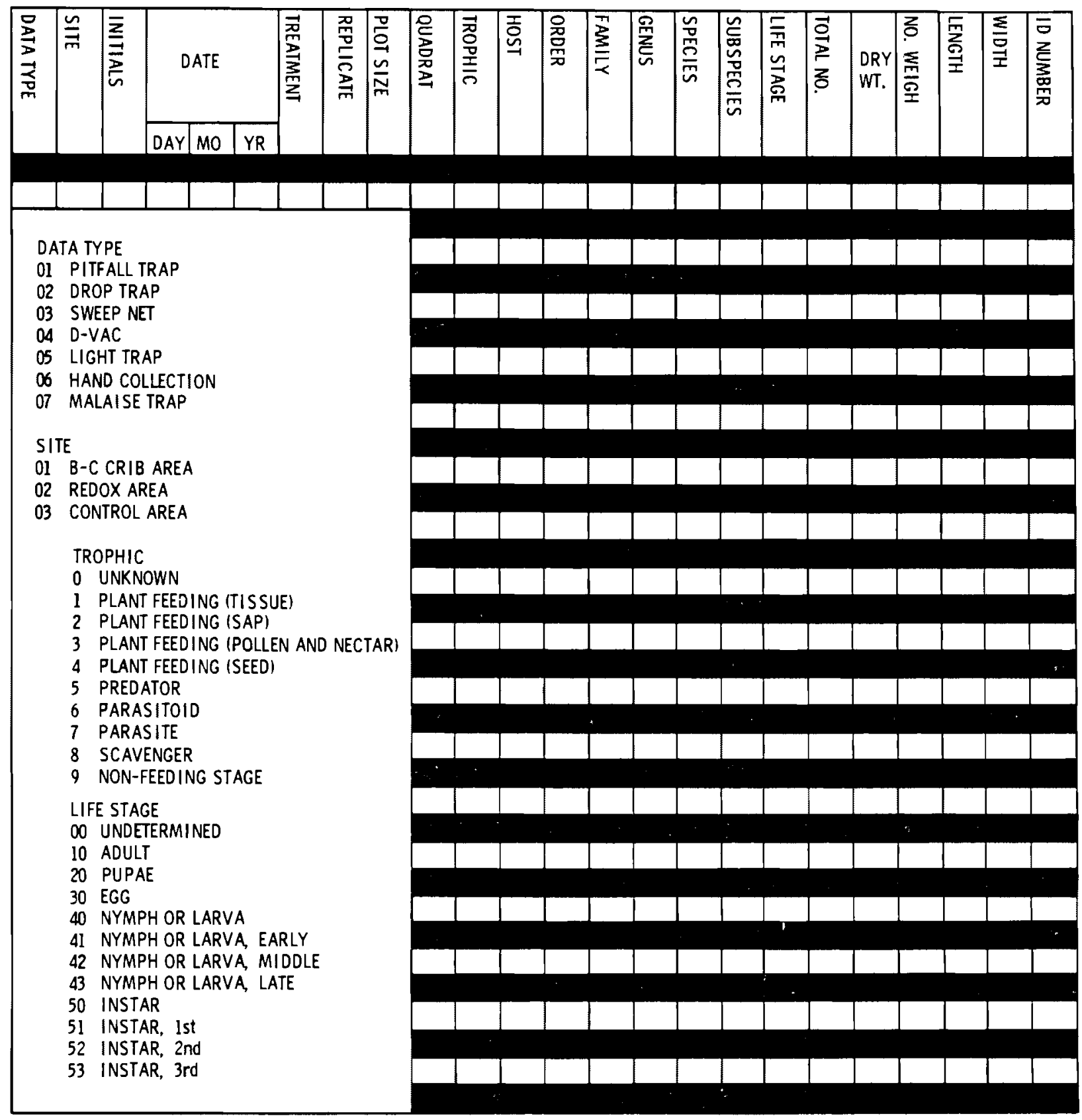

FIGURE 2. Shrub Insect Field Data Sheet 


\section{$\underline{\text { RESULTS }}$}

\section{SEASONAL DISTRIBUTION}

The seasonal distribution of insect abundance on big sagebrush is shown in Figure 3. Peak abundance occurred earlier in 1974 than the time span appearing in the diagram. The abundance values followed similar patterns in all three study areas, peaking in April or May of both study years.

Insect abundance associated with rabbitbrush and hopsage is shown in Figure 4. The seasonal pattern for insect abundance on rabbitbrush appears bimoda1, peaking in May or June and again during September and October. The June peak was comprised mostly of Homoptera (bugs) and Orthoptera (grasshoppers) but the October peak appeared to consist of several different taxa. There were no clear patterns of insect abundance on hopsage.

\section{INSECT TAXA ASSOCIATED WITH RABBITBRUSH}

Table 1 shows the relative abundance of invertebrate taxa associated with rabbitbrush. The rankings of these taxa were not significantly different $(\alpha=0.05)$ during both the 1974 and 1975 study years. Four taxa (Homoptera, Orthoptera, Araneida, and Hemiptera) accounted for $90 \%$ of individual specimens collected in 1974 and 83\% during the 1975 study season.

Homoptera are sucking insects, usually rather small and not readily apparent. Comprised completely of herbivorous species, they are usually among the most numerous of plant feeders (Hewitt et al., 1974). The Homoptera collected from rabbitbrush represented four different families, as indicated in Table 2. The most commonly encountered Homopterans were the leafhoppers. These insects occur on all types of native and cultivated vegetation and their abundance on rabbitbrush is not surprising. Aphids are also common on other rangeland plants but are more abundant on cultivated crops.

The occurrence of grasshoppers on rabbitbrush in the 200 Area plateau has been previously reported by Sheldon and Rogers (1978). The four main species collected during this study were Melanoplus cinereus, Melanop lus yarrowi i, Hesperotettix viridis, and Apote notabilis. Hesperotettix spp. has been described as a selective feeder on rabbitbrush (Sheldon and Rogers, 1978) and can usually be found either feeding or resting within the foliage of rabbitbrush. Melanoplus cinereus is also a shrub feeder but tends to concentrate on big sagebrush, feeding on rabbitbrush only incidentally. Both $A$. notabilis and $M$. yarrowi $i$ are very general feeders and would be expected to be found near rabbitbrush, as we 11 as a variety of other plants. 


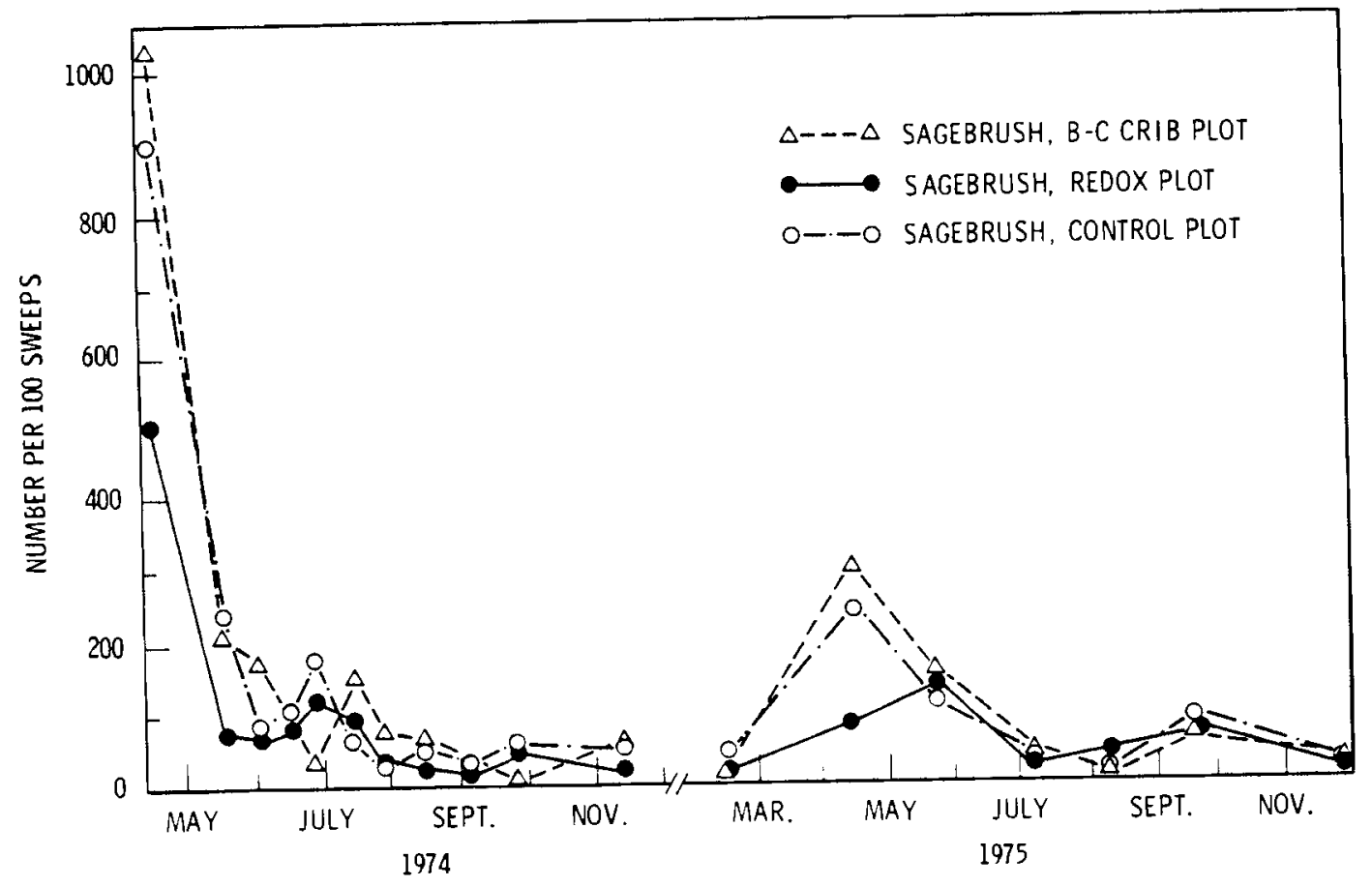

FIGURE 3. Seasonal Distribution of Insect Abundance on Sagebrush

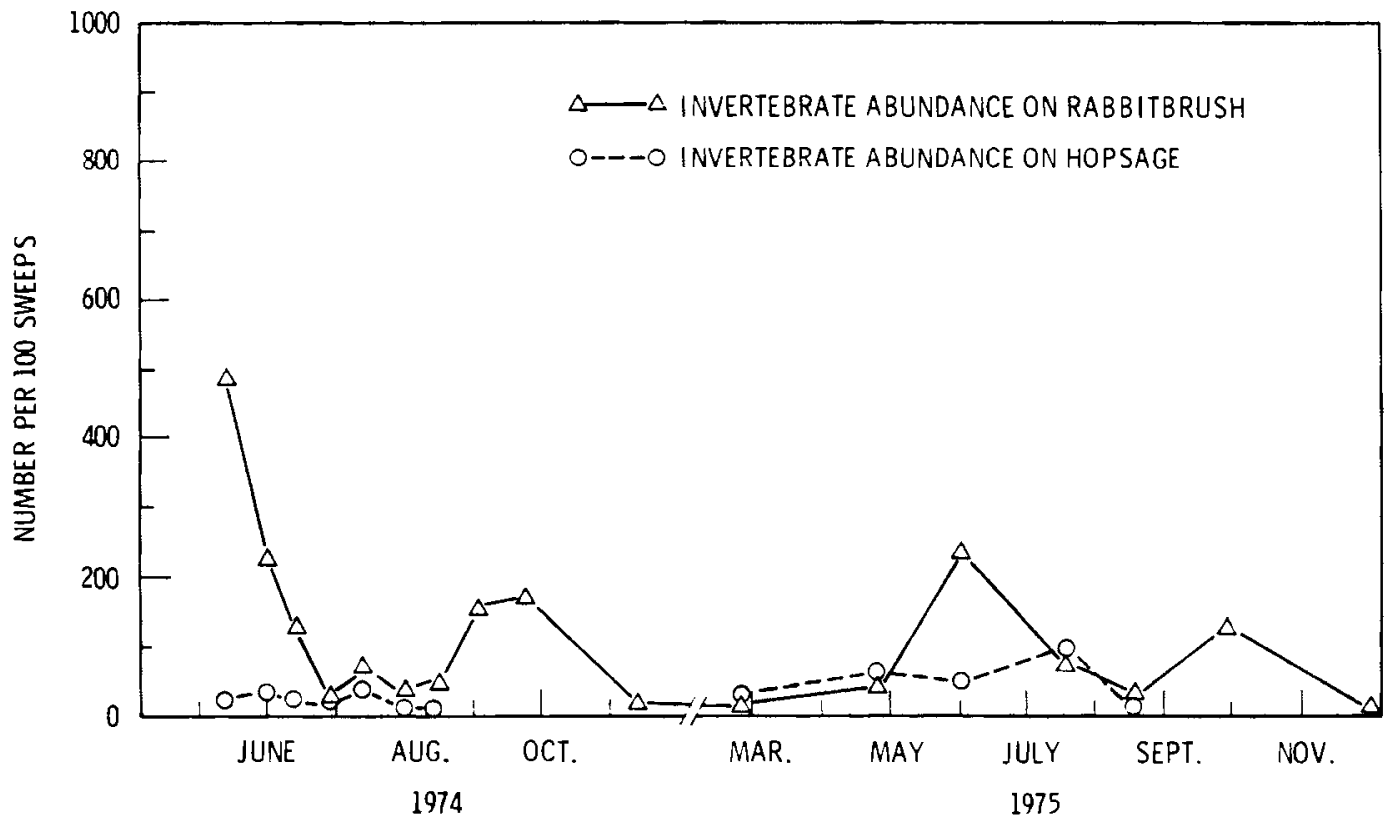

FIGURE 4. Seasonal Distribution of Insect Abundance on Hopsage and Rabbitbrush 
TABLE 1. Relative Abundance (\%) of Major Insect Taxa Collected from Rabbitbrush at the B-C Cribs Site During 1974 and 1975

\begin{tabular}{lcr}
\hline \multicolumn{1}{c}{ Taxa } & 1974 & 1975 \\
\hline Homoptera (bugs) & - & \\
\hline Orthoptera (gras shoppers) & 35.2 & 21.7 \\
Araneida (spiders) & 27.6 & 15.7 \\
Hemiptera (true bugs) & 15.0 & 34.1 \\
Lepidoptera (butterflies, moths) & 12.0 & 11.1 \\
Hymenoptera (ants, bees, wasps) & 5.5 & 7.6 \\
Diptera (flies) & 2.7 & 3.5 \\
Coleoptera (beet les) & 1.0 & 1.5 \\
Neuroptera (lace wings) & 0.8 & 4.6 \\
Others & 0.2 & 0.4 \\
& 0.2 & 0.0 \\
\hline
\end{tabular}

TABLE 2. Homoptera Families Collected from Rabbitbrush Samp les

\begin{tabular}{lc}
\hline \multicolumn{1}{c}{ Family } & $\begin{array}{c}\text { Total } \\
\text { Number } \\
\text { Collected }\end{array}$ \\
\hline Aleyrodidae (whiteflies) & 1 \\
Aphidae (aphids) & 24 \\
Cicadellidae (leafhoppers) & 422 \\
Psyllidae (plant lice) & 4 \\
\hline
\end{tabular}


The spiders associated with rabbitbrush were not routinely identified beyond the order (Araneida) level. Several common families were noted, however. These were Clubionidae (two-clawed hunting spiders), Salticidae (jumping spiders) and Thomisidae (crab spiders).

\section{INSECT TAXA ASSOCIATED WITH HOPSAGE}

The relative abundance of invertebrate taxa associated with hopsage is shown in Table 3. Rankings of collected taxa showed no significant difference $(\alpha=0.05$ ) between the 1974 and 1975 study years.

The Orthoptera (grasshoppers), Coleoptera (beetles) and Araneida (spiders) were clearly the three dominant taxa occupying hopsage. The Chrysomelids (leaf beetles) were the dominant beetle group present. Both the adult and immature stages of this beetle group are plant feeders and many species are serious pests to both native and cultured plants. Interestingly, there were relatively few Hemiptera or Homoptera collected from hopsage, indicating that the sucking insects do not heavily utilize this shrub.

There were a few Lepidoptera associated with hopsage, most of them belong ing to the family Geometridae. Observations conducted during 1973 as part of another study showed an abundance of Coleophoridae on hopsage plants near the 200 Area plateau. This is a family of small case-bearing moths. The larvae construct cases composed of silk, bits of leaves, and excrement. They carry these about for protection and extend their heads from the cases to eat leaf material. They have not been detected in abundance since 1973 but presumably could occur in greater numbers at any time.

\section{INSECT TAXA ASSOCIATED WITH SAGEBRUSH}

The relative abundance of invertebrate taxa associated with big sagebrush is shown in Tables 4-6. Big sagebrush was sampled near the B-C Cribs area, the Redox area, and the control area. Hemiptera and Homoptera proved to be the most frequently collected taxa from all study areas. Analys is by ranking of relative abundance of collected specimens showed no significant differences $(\alpha=0.05)$ between study locations or between study years (Table 7).

The Hemiptera collected from big sagebrush represented seven different families as shown in Table 8 . The plant bugs were by far the most common Hemipteran family associated with sagebrush. This family is the largest in the order and its members can be found on most types of vegetation. Some species are reported to be serious pests of agricultural crops but none have been recorded as major consumers of sagebrush. However, this may be partly because their feeding habits are harder to observe. Since they have sucking mouth parts, their feeding activities are not as apparent as some of the defoliating insect feeders (Lepidopteran larvae, beetles, etc). The Homoptera found associated with sagebrush represented the five families shown in Table 9. The leafhopper family (Cicadellidae) is clearly the most common Homopteran associated with sagebrush. Leafhoppers constitute a very large 
TABLE 3. Relative Abundance (\%) of Major Insect Taxa Collected from Hopsage During 1974 and 1975 at the Control Site

\begin{tabular}{lcr}
\hline \multicolumn{1}{c}{ Taxa } & 1974 & 1975 \\
\hline Orthoptera (grasshoppers) & $--.--\%----$ \\
Coleoptera (beetles) & 30.3 & 15.9 \\
Araneida (spiders) & 19.1 & 33.2 \\
Diptera (flies) & 13.6 & 26.7 \\
Homoptera (bugs) & 10.5 & 1.7 \\
Hymenoptera (ants, bees, wasps) & 9.9 & 3.5 \\
Hemiptera (true bugs) & 7.4 & 4.7 \\
Lepidoptera (butterflies, moths) & 6.8 & 6.0 \\
Neuroptera (lace wings) & 2.5 & 7.3 \\
Other & 0.0 & 0.4 \\
& 0.0 & 0.4 \\
\hline
\end{tabular}

TABLE 4. Relative Abundance (\%) of Major Insect Taxa Collected from Big Sagebrush During 1974 and 1975 at the B-C Cribs Site

\begin{tabular}{lcr}
\hline \multicolumn{1}{c}{ Taxa } & 1974 & 1975 \\
\hline Hemiptera (true bugs) & 57.5 & 42.4 \\
Homoptera (bugs) & 25.8 & 34.0 \\
Orthoptera (grasshoppers) & 7.9 & 8.5 \\
Araneida (spiders) & 4.4 & 5.7 \\
Hymenoptera (ants, bees, wasps) & 2.4 & 3.6 \\
Diptera (flies) & 0.9 & 1.3 \\
Lepidoptera (butterf1ies, moths) & 0.6 & 1.4 \\
Coleoptera (beetles) & 0.3 & 2.5 \\
Neuroptera (lace wings) & 0.2 & 0.5 \\
\hline
\end{tabular}


TABLE 5. Relative Abundance (\%) of Major Insect Taxa Collected from Big Sagebrush During 1974 and 1975 at the Redox Site

\begin{tabular}{lcr}
\hline \multicolumn{1}{c}{ Taxa } & 1974 & 1975 \\
\hline & & \\
\hline Homoptera (bugs) & 41.6 & 43.8 \\
Hemiptera (true bugs) & 37.8 & 21.1 \\
Araneida (spiders) & 6.8 & 17.3 \\
Orthoptera (grasshoppers) & 6.3 & 5.7 \\
Hymenoptera (ants, bees, wasps) & 4.1 & 4.1 \\
Lepidoptera (butterflies, moths) & 1.1 & 3.0 \\
Coleoptera (beet les) & 1.0 & 1.9 \\
Diptera (flies) & 1.0 & 2.7 \\
Neuroptera (lace wings) & 0.3 & 0.3 \\
Other & 0.1 & 0.0 \\
& & \\
\hline
\end{tabular}

TABLE 6. Relative Abundance (\%) of Major Insect Taxa Collected from Big Sagebrush During 1974 and 1975 at the Control Site

\begin{tabular}{lcr}
\hline \multicolumn{1}{c}{ Taxa } & 1974 & 1975 \\
\hline Hemiptera (true bugs) & $-----\%$ & \\
\hline Homoptera (bugs) & 42.8 & 35.8 \\
Araneida (spiders) & 34.9 & 27.3 \\
Orthoptera (grasshoppers) & 6.4 & 8.2 \\
Hymenoptera (ants, bees, wasps) & 6.4 & 9.5 \\
Lepidoptera (butterflies, moths) & 5.8 & 6.3 \\
Diptera (flies) & 1.4 & 1.7 \\
Coleoptera (beetles) & 1.0 & 1.7 \\
Neuroptera (lace wings) & 1.0 & 9.0 \\
Other & 0.3 & 0.5 \\
& 0.1 & 0.0 \\
\hline
\end{tabular}


TABLE 7. Insect Taxa Rankings Collected from Big Sagebrush on B-C Cribs, Redox Pond and Control Study Areas

\begin{tabular}{lcc}
\hline Study Location & 1974 & 1975 \\
\hline & $--R_{S}$ Value-- \\
B-C Cribs versus Redox Pond & 0.96 & 0.92 \\
B-C Cribs versus Control & 0.98 & 0.95 \\
Redox Pond versus Control & 0.98 & 0.78 \\
\hline
\end{tabular}

TABLE 8. Hemiptera Families Collected from Big Sagebrush

\begin{tabular}{llr}
\hline \multicolumn{1}{c}{ Family } & Common Name & $\begin{array}{c}\text { Total } \\
\text { Number } \\
\text { Collected }\end{array}$ \\
\hline Coreidae & Leaf-footed bug & 1 \\
Lygaeidae & Seed bug & 18 \\
Miridae & Plant bug & 531 \\
Nabidae & Damsel bug & 33 \\
Pentatomidae & Stink bug & 3 \\
Pyrrhocoridae & Red bug & 2 \\
Scutelleridae & Shield-back bug & 1 \\
\hline
\end{tabular}


group and inhabit trees, shrubs, flowers, and crop plants. There are many economically important pest species within the leafhopper family but none have been reported as serious pests of sagebrush.

TABLE 9. Homoptera Families Associated with Sagebrush

\begin{tabular}{llr}
\hline & Common Name & $\begin{array}{c}\text { Total } \\
\text { Number } \\
\text { Collected }\end{array}$ \\
\hline Aphididae & aphid & 84 \\
Cicadellidae & leafhopper & 412 \\
Dictyopharidae & plant hopper & 4 \\
Ortheziidae & coccids & 14 \\
Psyllidae & plant lice & 34 \\
\hline
\end{tabular}

\section{COMPARISON OF SHRUB INVERTEBRATE FAUNA}

A comparison of the relative abundance of invertebrates inhabiting sagebrush, rabbitbrush and hopsage plants for both study years combined is shown in Table 10. Hemiptera and Homoptera were the two groups most commonly collected from sagebrush. Homoptera, Orthoptera and Araneida (spiders) were the most frequent taxa collected from rabbitbrush and Orthoptera, Araneida, and Coleoptera were the common inhabitants collected from hopsage.

The invertebrate fauna inhabiting sagebrush and rabbitbrush were found to be equivalent in terms of taxonomic rankings during both study years $(\alpha=0.01)$. Comparisons of the sagebrush-hopsage and rabbitbrush-hopsage fauna showed significant differences in the relative rankings of taxa during all study years $(\alpha=0.01)$. This analys is of the taxonomic rankings for invertebrates inhabiting sagebrush, hopsage, and rabbitbrush is shown in Table 11. 
TABLE 10. Relative Abundance of Insect Taxa Collected from Sagebrush, Rabbitbrush and Hopsage

\begin{tabular}{lccr}
\hline \multicolumn{1}{c}{ Taxa } & Sagebrush & Rabbitbrush & Hopsage \\
\hline & & & \\
Hemiptera (true bugs) & 44.6 & 11.7 & 6.4 \\
Homoptera (bugs) & 33.0 & 31.2 & 6.1 \\
Orthoptera (grasshoppers) & 7.3 & 24.0 & 21.8 \\
Araneida (spiders) & 6.5 & 20.7 & 21.3 \\
Hymenoptera (ants, bees, wasps) & 4.2 & 2.9 & 5.8 \\
Coleoptera (beetles) & 1.7 & 1.9 & 27.4 \\
Lepidoptera (butterf1ies, moths) & 1.2 & 6.1 & 5.3 \\
Diptera (flies) & 1.1 & 1.2 & 5.3 \\
Neuroptera (lace wings) & 0.3 & 0.3 & 0.3 \\
Other & 0.1 & 0.1 & 0.3 \\
\hline
\end{tabular}

TABLE 11. Insect Taxa Rankings from Sagebrush, Rabbitbrush and Hopsage

\begin{tabular}{lll}
\hline \multicolumn{1}{c}{ Shrub } & 1974 & 1975 \\
\hline Sagebrush versus Rabbitbrush & 0.91 & 0.85 \\
Sagebrush versus Hopsage & $0.39 *$ & $0.52 *$ \\
Rabbitbrush versus Hopsage & $0.52 *$ & $0.67 *$ \\
& & \\
\hline * Significantly different $(\alpha=0.01)$ &
\end{tabular}




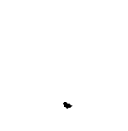




\section{DISCUSSION}

Shrubs help stabilize landscapes, provide food and cover for wildlife and provide some forage for cattle and horses (Hewitt et al., 1974). Information about insects on native western rangeland shrubs is fragmentary and meager. Essig's (1934) Insects of Western North America is perhaps the best single source of information, but much of it is dated. This study assesses the insect populations associated with three major shrub species: big sagebrush, rabbitbrush and hopsage.

\section{$\underline{\text { SAGEBRUSH }}$}

Sagebrush covers approximately $667,000,000$ ha of western lands (Beet le, 1960). It is a dominant shrub on three DOE lands: the Hanford Site (Rogers and Rickard, 1977), Nevada Test Site (O'Farrell and Emery, 1976) and the Idaho National Engineering Laboratory (McBride et al., 1978) and is therefore an important ecological component of DOE-managed lands. Insect groups known to be important consumers of sagebrush include the defoliators, leaf beetles, grasshoppers and darkling beetles.

\section{Aroga websteri}

Defoliating insects are the most serious insect threat to sagebrush plants. Aroga websteri (Lepidoptera:Gelechiidae) has probably been the most destructive defoliator of sagebrush on western rangelands. Serious blights have occurred in Nevada, Oregon and California and about 15,000,000 ha of rangelands were reported to have been defoliated in Washington (Ha11, 1964). It apparently has not been a serious pest at Hanford.

\section{Leaf Beetles}

The leaf beetles (Coleoptera:Chrysomelidae) are also sagebrush consumers. Pringle (1960) reported that these insects killed up to $80 \%$ of the sagebrush in a 3,000-acre area near Kamloops, British Columbia. Leaf beetles were found on sagebrush at Hanford during this study. They occurred in fairly low numbers, however, and are not currently regarded as a threat to 200 Area sagebrush stands.

\section{Grasshoppers}

The migratory grasshopper (Melanoplus sanguinipes) was reported to have defoliated thousands of acres of sagebrush in Montana during 1939 (Hewitt et al., 1974). Allred (1941) reported that two grasshopper species, Aulocara elliotij and Ageneotettix deorum, destroyed $50 \%$ of the sagebrush p iants in the Little Powder River drainage of Wyoming and Montana. All three of these grasshopper species occur here at Hanford, although Aulocara elliottij occurs 
in low numbers. It will probably not become an important consumer of sagebrush as long as the vegetation complex remains unchanged. A detailed analysis of the food habits of 200 Area plateau grasshoppers revealed neither the migratory grasshopper nor Ageneotettix deorum to be a major sagebrush feeder. Two other grasshopper species (Melanoplus cinereus and 0edaleonotus enigma) were found to select sagebrush (Sheldon and Rogers, 1978), and any increase in the ir population densities could seriously impact sagebrush stands.

Dark ling Beetles

Sagebrush was identified as a major component in the diet of two darkling beetle species (Rogers et al., 1978). Eleodes humeralis ingested sagebrush with a frequency of $51 \%$ and Eusattus muricatus with a frequency of $50 \%$. Eleodes humeral is occurs in abundance only in shrub-dominated areas and has been observed feeding on the foliage. The feeding habits of Eusattus are unclear. It may feed on the foliage but more probably it ingests sagebrush material from the litter layer.

$\underline{\text { Galls }}$

Sagebrush plants at the Hanford Site and elsewhere are commonly infested with galls. The galls at Hanford are induced by the reproductive habits of flies (Cecidomyiidae and Tephritidae) and wasps (Torymidae). There is no evidence that these galls hamper the survival of the sagebrush plants (Hewitt et al., 1974).

\section{RABBITBRUSH}

Little data has been published on the extent of insect feeding on rabbitbrush. Larvae of Synnoma lynosyrana (Lepidoptera:Tortricidae) have been reported to have killed rabbitbrush in areas of Idaho and Montana (Pletsch, 1938). Large areas of rabbitbrush in New Mexico were also killed by this species (Hewitt, 1974). Larvae stripped the leaves from large plants and ate young plants down to ground level.

Dietary analys is revealed rabbitbrush to be one of only two shrubs important as plant foods for Hanford darkling beetles, occurring with a frequency of $36 \%$ in the diet of Eleodes humeralis (Rogers et al., 1978). The grasshopper species Hesperotettix viridis was found to feed almost exclusively on rabbitbrush at the Hanford Site (Sheldon and Rogers, 1978).

HOPSAGE

Although hopsage occurs throughout most of the foothills and desert valley regions of the western United States, almost nothing is known about associated insect consumers. Information obtained from this study indicates that the insect taxa associated with hopsage were different from the taxa associated with either sagebrush or rabbitbrush. The limited distribution of communities dominated by hopsage on the 200 Area plateau makes the need for information concerning associated insect inhabitants less critical than for those associated with sagebrush and rabbitbrush stands. 


\section{REFERENCES}

Allred, B. W. 1941. Grasshoppers and their effect on sagebrush on the Little Powder River in Wyoming and Montana. Ecology 22(4):387-392.

Beetle, A. A. 1960. A study of sagebrush. Wyo. Agr. Exp. Sta. Bu11. 368 . $83 \mathrm{pp}$.

Cline, J. F., D. W. Uresk and W. H. Rickard. 1975. Characterization of plant communities adjacent to the B-C Cribs controlled area and Redox Pond areas on the 200 Area plateau. BNWL-1916. Battelle, Pacific Northwest Laboratories, Richland, WA. 57 pp.

Dixon, W. J. and F. J. Massey. 1969. Introduction to statistical analysis. McGraw-Hi11 Book Company, NY. 638 pp.

Essig, E. 0. 1934. Insects of western North America. Macmillan, NY. $1035 \mathrm{pp}$.

Ha11, R. C. 1964. Impact on antelope and deer sagebrush ranges by the sagebrush defoliator Aroga websteri. USDA Forest Service Detection Reprint 5220. U.S. Government Printing Office, Washington, DC. 12 pp.

Hewitt, G. B., E. W. Huddleston, R. J. Lavigne, D. N. Ueckert and J. E. Watts. 1974. Rangeland entomology. Soc. for Range Manage., Range Sci. Ser 2. $127 \mathrm{pp}$.

McBride, R., N. R. French, A. H. Dahl and J. E. Detmer. 1978. Vegetation types and surface soils of the Idaho National Engineering Laboratory site. IDO-12084. Department of Energy, Idaho Falls, ID. 29 pp.

O'Farre11, T. P. and L. A. Emery. 1976. Ecology of the Nevada Test Site: A narrative summary and annotated bibliography. NVO-167. Desert Res. Inst., Boulder City, NV. 249 pp.

Pletsch, D. J. 1938. Outbreak of Synnoma lynosyrana Waisingham (Tortricidae, Lepidoptera). Entomol. News 49:231.

Pringle, W. L. 1960. The effect of a leaf feeding beetle on big sagebrush in British Columbia. J. Range Manage. 13:139-142.

Rogers, L. E. and W. H. Rickard. 1977. Ecology of the 200 Area plateau waste management environs: A status report. PNL-2253. Pacific Northwest Laboratory, Richland, WA. 
Rogers, L. E., N. Woodley, J. K. Sheldon and V. A. Uresk. 1978. Darkling beetle populations (Tenebrionidae) at the Hanford Site in southcentra 1 Washington. PNL-2465. Pacific Northwest Laboratory, Richland, WA.

Sheldon, J. K. and L. E. Rogers. 1978. Grasshopper food habits within a shrub-steppe community. Oecologia 32:85-92.

Siege 1, S. 1956. Nonparametric statistics for the behavioral sciences. McGraw-Hi11, NY. 312 pp.

Stone, W. A., D. E. Jenne and J. M. Thorp. 1972. Climatography of the Hanford Area. BNWL-1605. Battelle, Pacific Northwest Laboratories. Rich land, WA. $257 \mathrm{pp}$. 
APPENDIX A

SHRUB-INHABITING INSECT DATA 

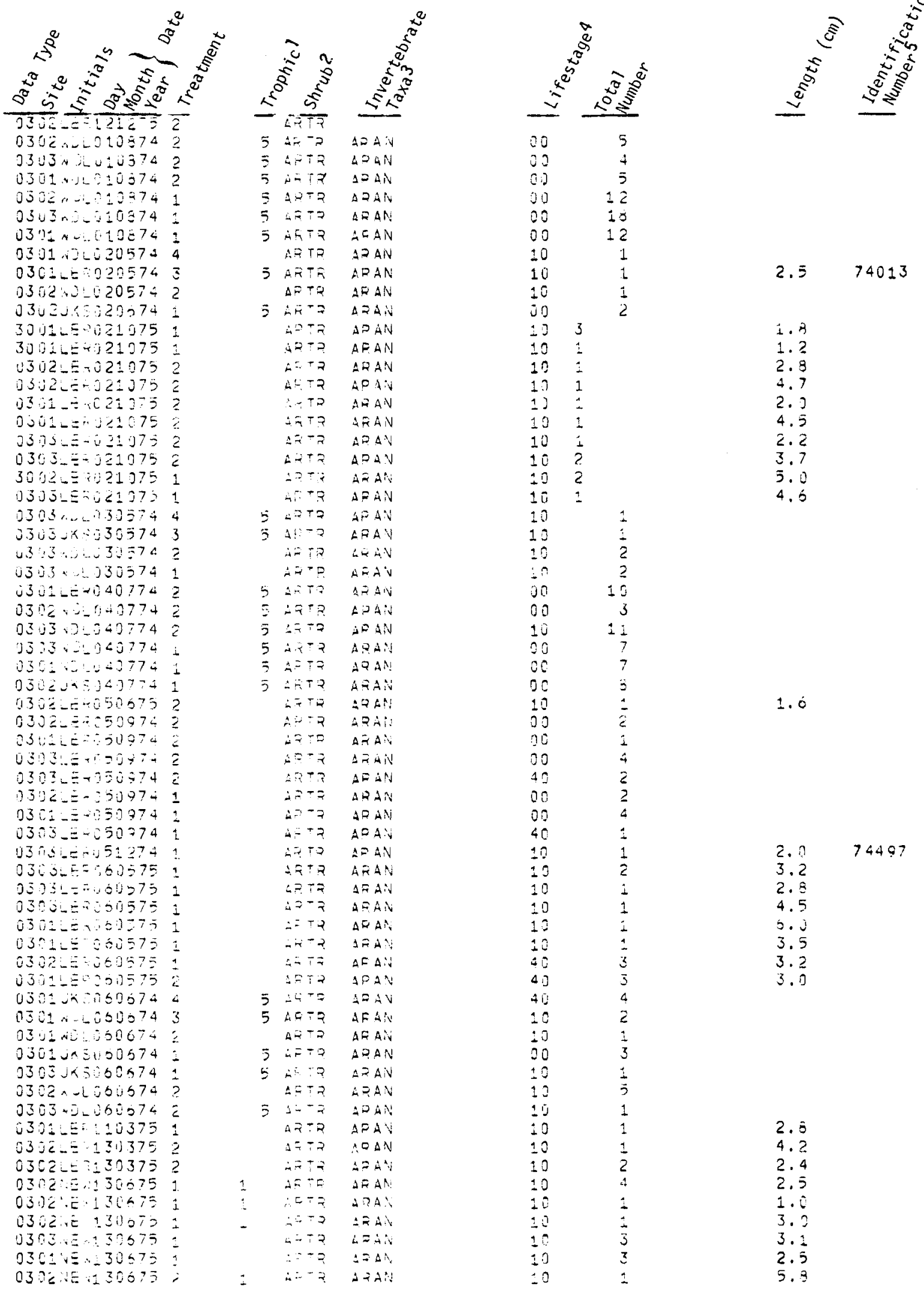

A. 1 


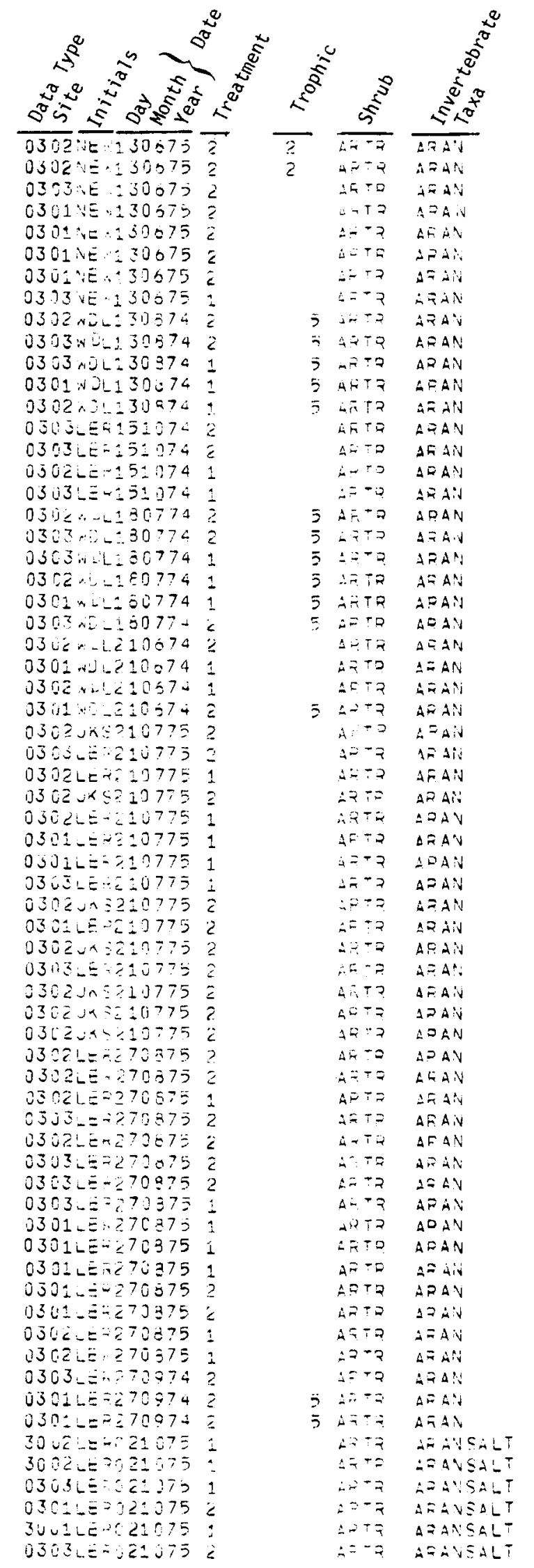

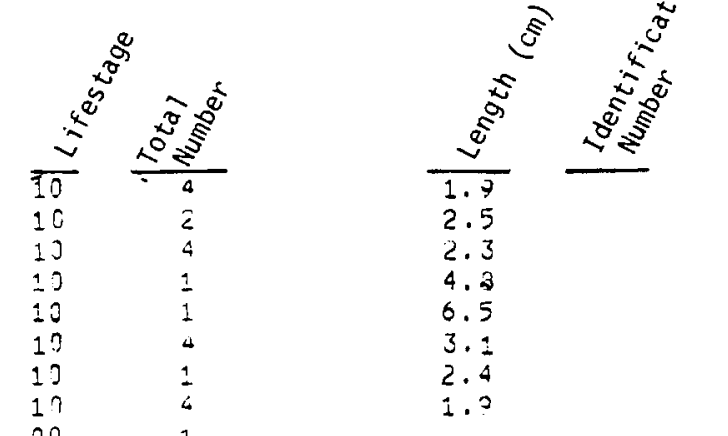

5.0

2. d

5.5

6.3

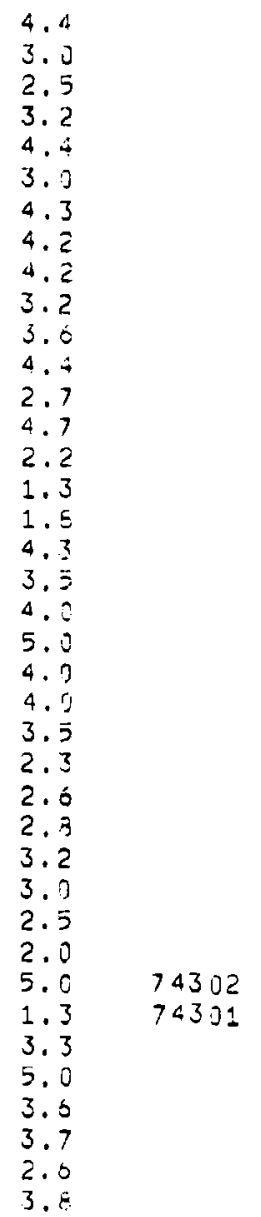

A. 2 

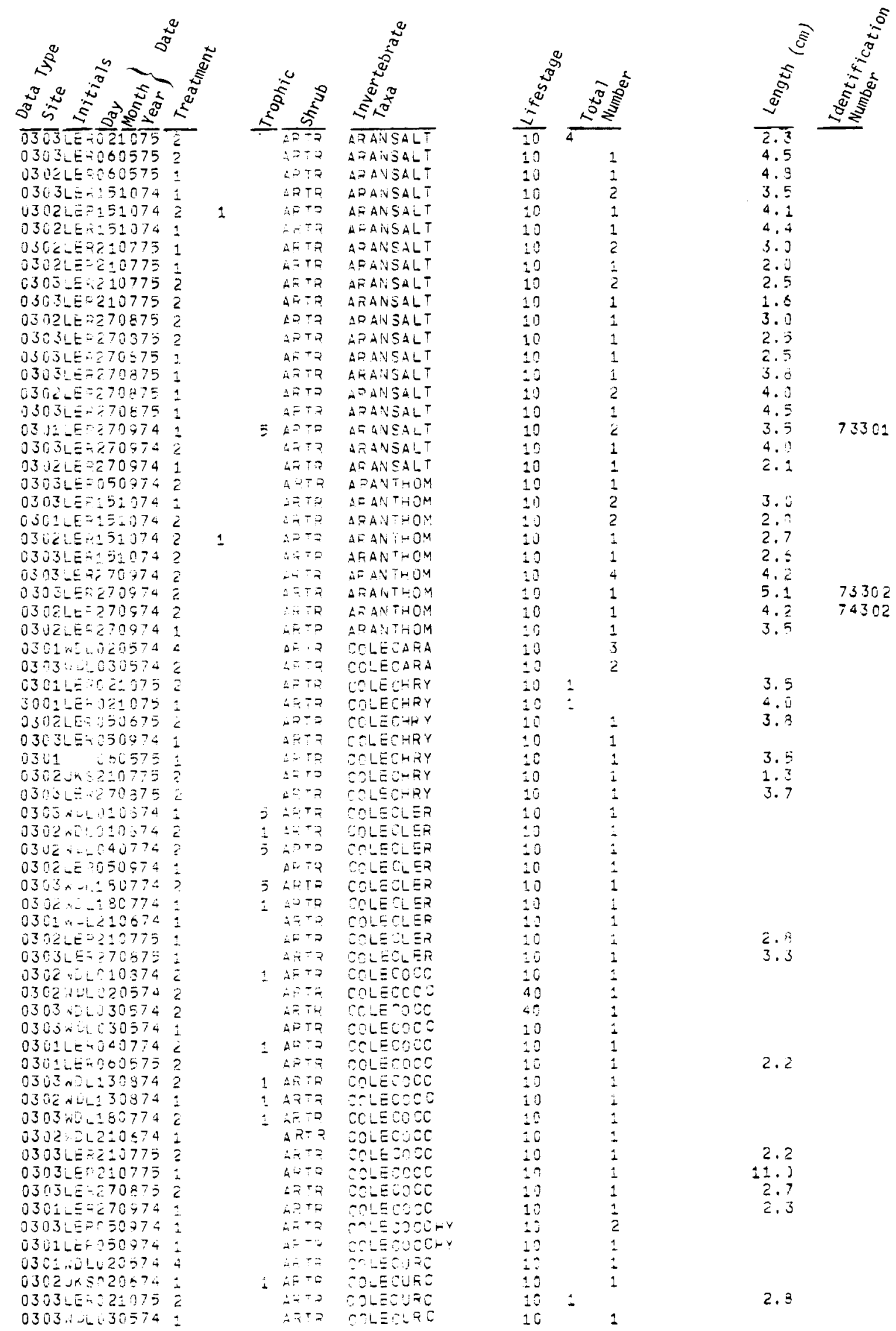

3.5

3. 3

3.5

3.7

2. 18

3.3

2.2

2. 2

11.]

2.7

2. 3

2.3

A. 3 

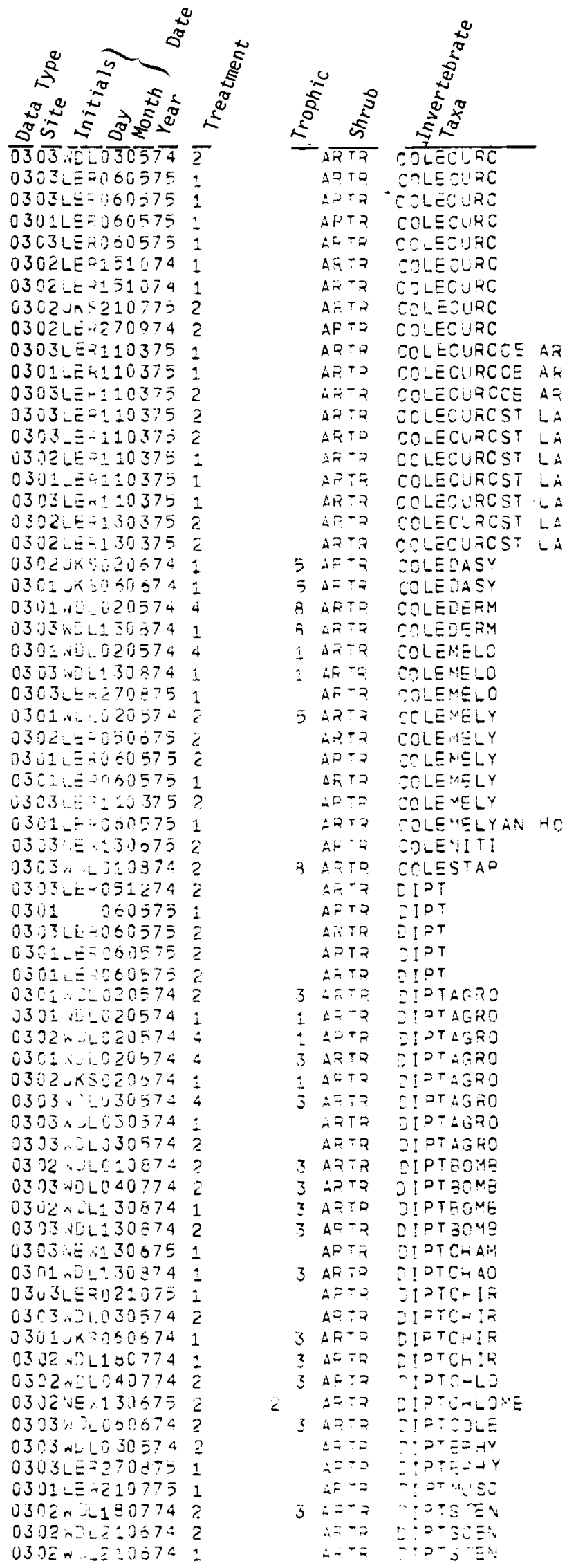

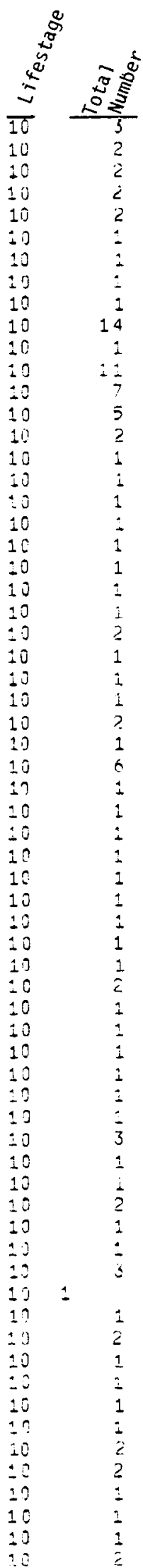

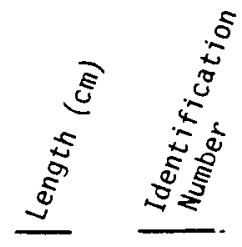

2.9

3.2

3.2

3.7

2. 2

2.5

3.1

2.6

2.5

3.?

2.8

4.4

4.0

5.?

4.8

5.5

4.7

5.2

$\forall, J$

3.0

3. ?

2.9

3.:

3.2

2. ?

1. 0

1.5

1.5

74798

2. 4

1.7

1.6

4.

1.0

6.5 


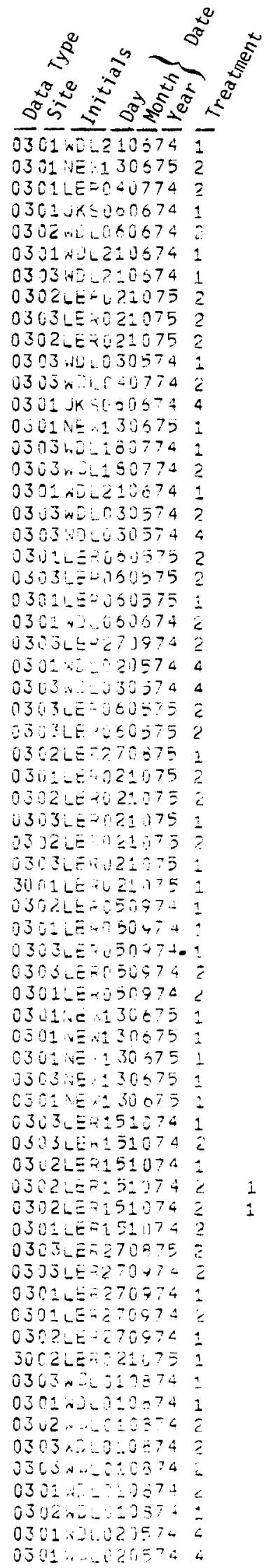

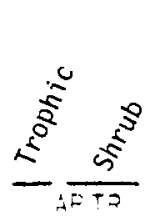

AF TQ

$\Delta=F \quad \because P T S C I A$

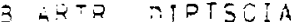

मH:R EIPTSEIA

$A B T=$ ZIPTSCIA

3 LFTE IIFTSCIA

ATTR DIPTSIMU

$A P T R$ DIPTSIMU

ARTF EIPTTACH

$A D T D$ IPTTACH

3 AP $: R$

3 A $\bar{A}=0$

$\Delta=T 7$

มंख

4 $4 \div \%$

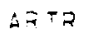

$\triangle P+2$

ATTE

आ०

ม⿻丁𠃋

i $27 \%$

$A C \div Q$

APT:

यन TQ

$i$ i

AL $=$ P

A $1 T=$

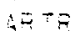

$A T \div 0$

$A R T 2$

的 $=$

AF $=$ ?

in $=$

$\lambda=-2$

$A \bar{T}=$

मींद

AใT

$A \bar{T} T$

मद八

$\Delta=T P$

AETP

$A F \div=$

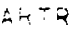

$A F T P$

$A=T F$

$\triangle E+Q$

AFTR

Aरं?

Aदि $\Rightarrow$

Aक्र十

$d \vec{i}+\vec{a}$

IRT

मिंर

$2 \quad a=-7$

if

म小ए

?

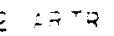

$2 \quad \therefore=-2$

c $\quad:=?$

?

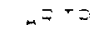

公证我

$\therefore=T 2$

$\dot{x}=-7$

IIPTTA

EDPTTACH

OPTIACL

IPT TACH

OIPTTACH

DIPTTAEH

กIPTTEPH

IPT TEPH

DIPTTEPH

IPY TEFA

OF TTEPH

IDT IEFH

DIPTTEEA

i PTT:PU

JIPT J

Z:PTTIP

TIPTTIPL

WEMICORE

UEM ILIGA

-EYIIYGA

MEMILYSA

LEDILYID

UEMILYGA

LE MILYSA

-EM LLYSA

HE MI L. ISA

HEMILYGA

HEM L Y GH

-UMILYGA

HEMILVGA

WEMILYGA

WC M! LYGA

$4 \equiv M I-Y G A$

HE

HEMILYJA

DE I I L V JA

HEMILYGA

WEMILYGA

HE IILYGA

WEM!LYOA

HㄷMII Y YAA

HEMILYGA

HEMILYEA

$H E M[L V G A$

HEM!LYGM

JEM! "I ?:

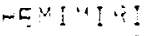

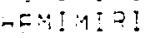

तE "I "द

म二

더 4 I

HEV $-2: \div$

- $=$ i ! ! ? I

- $=$ M : :

HEMILVGALV KA

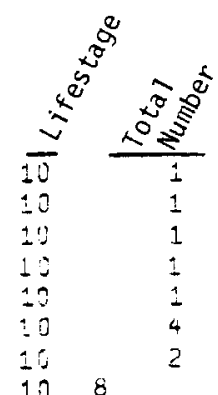

$\underbrace{5}$

3.9

2.5

3. 3

6.1

5.6

2. 7

3.3

2.5

10.7

15.5

14.2

1.3

.

3.7

2.3

3. 3

$3 . ?$

3.5

3.0

1. 1

2.

1.

3.

11

3.5

3. 2

$10 . \therefore$

3. 5

74318

3.1

3.?

4.0

2.?

3,5

$\pm 0.3$ 


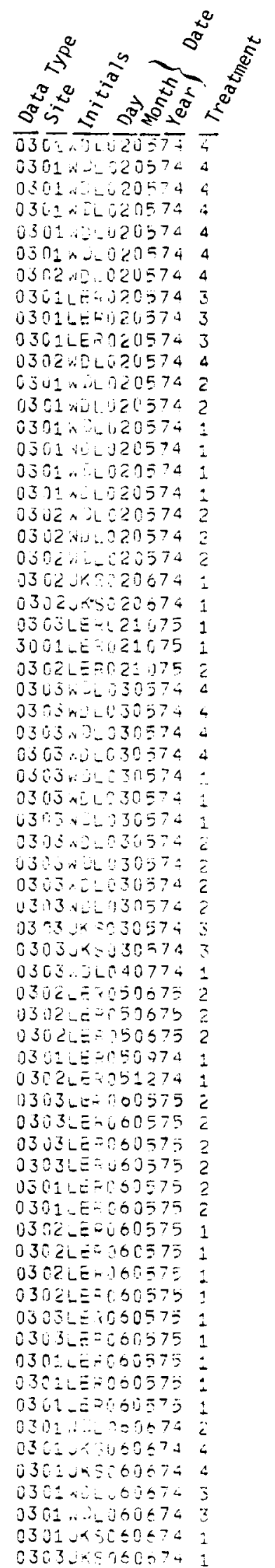

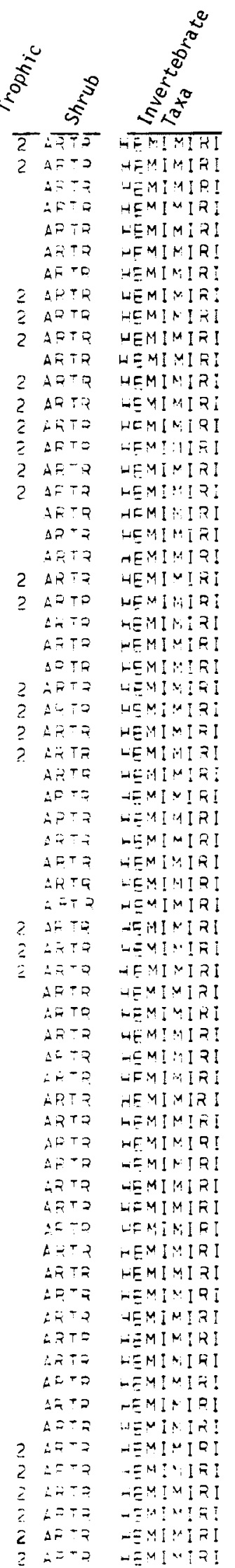

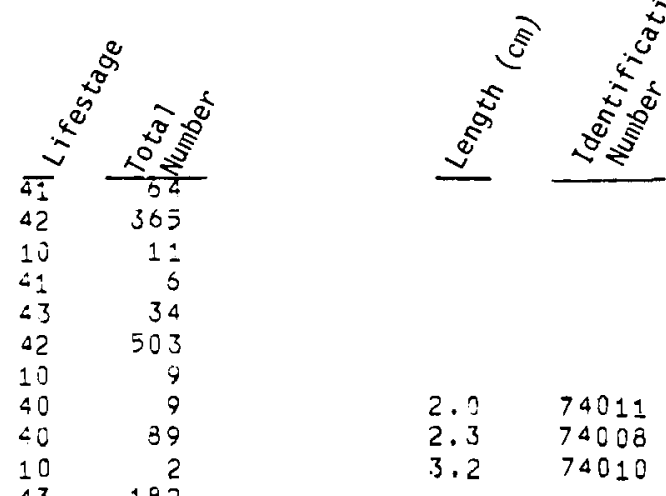

5.7

2.4

3.3

2.4

1.6

1.0

5.2

3.7

2.

1.5

$1 \cdot 2$

1.3

1. 9

1.2

1.5

2.6

1. 7

2. 3

1.5

2.?

1.5
1.2

A. 6 

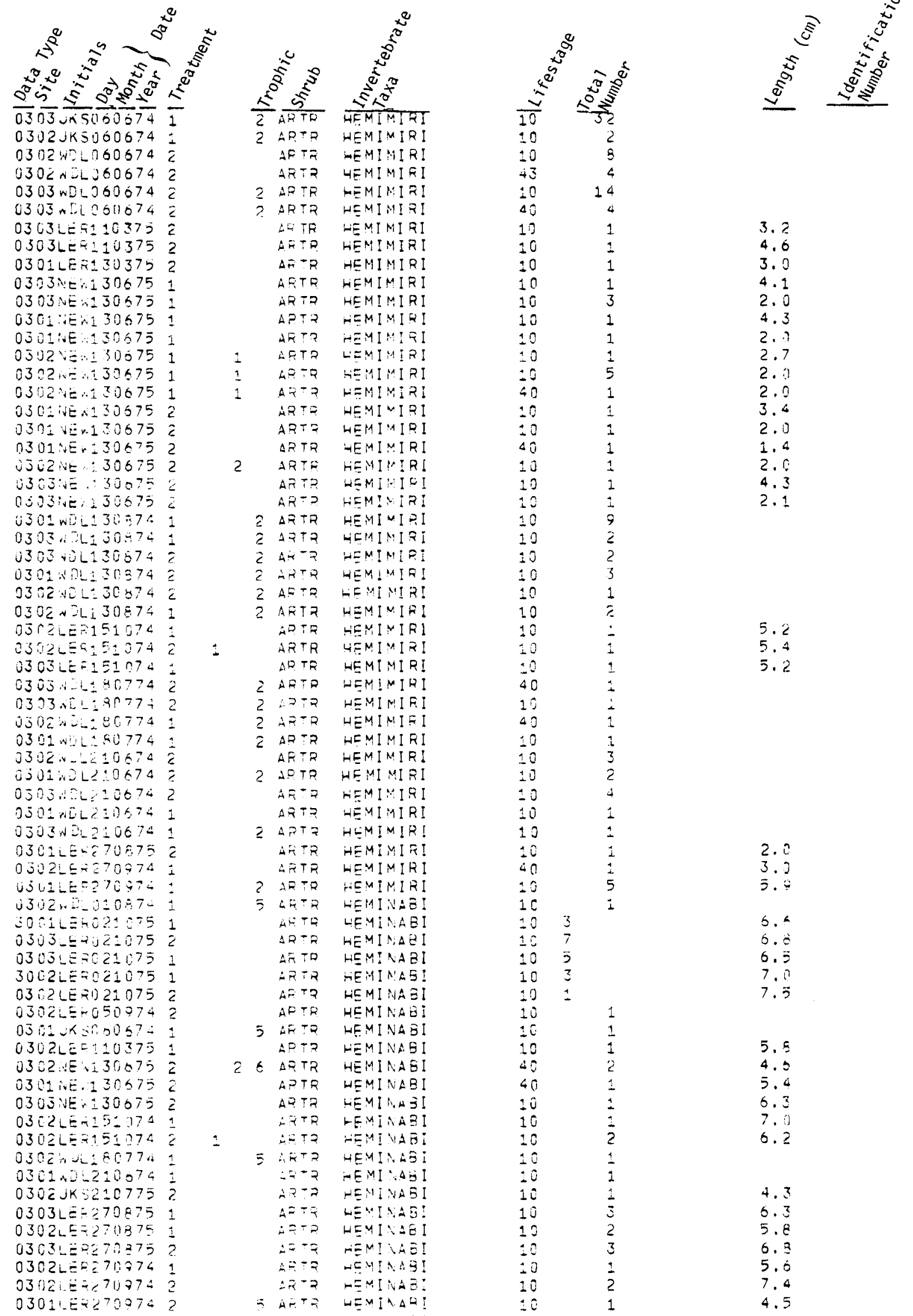

3.2
4.6
3.0
4.1
2.0
4.3
2.7
2.7
2.9
2.0
3.4
2.0
1.4
2.0
4.3
2.1

5.2

5.2

2.2

3.2

5.0

6.4

6.8

6.3

$7 . ?$

5.5

4.5

5.4

6. 3

7.0

6. ?

4.3

6.3

5.8

6.3

5.6

7.4

A. 7 

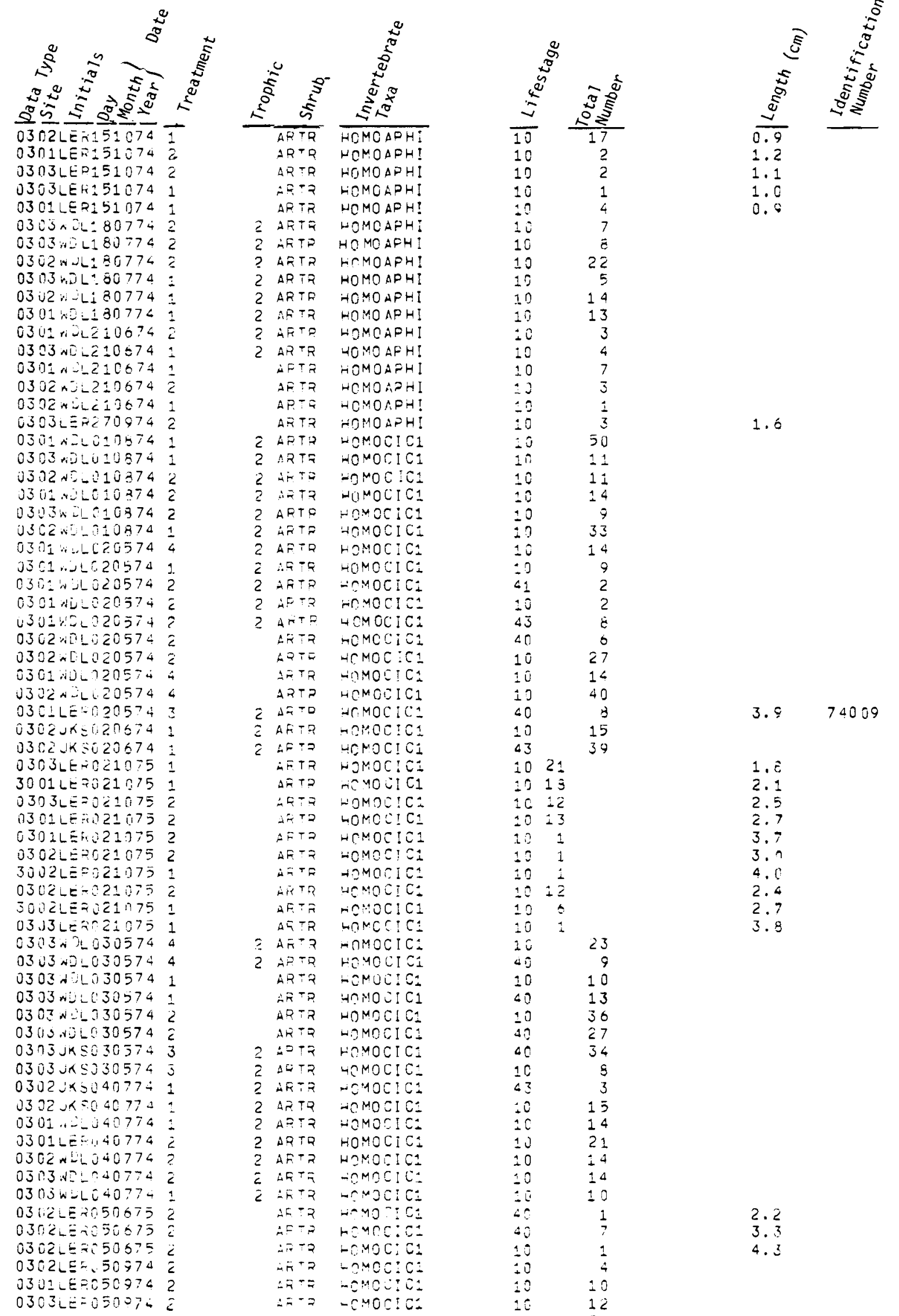

1.6

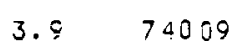

1. $E$

2. 1

2.5

2. 7

3.7

3. 9

4.8

2.4

2.7

23 


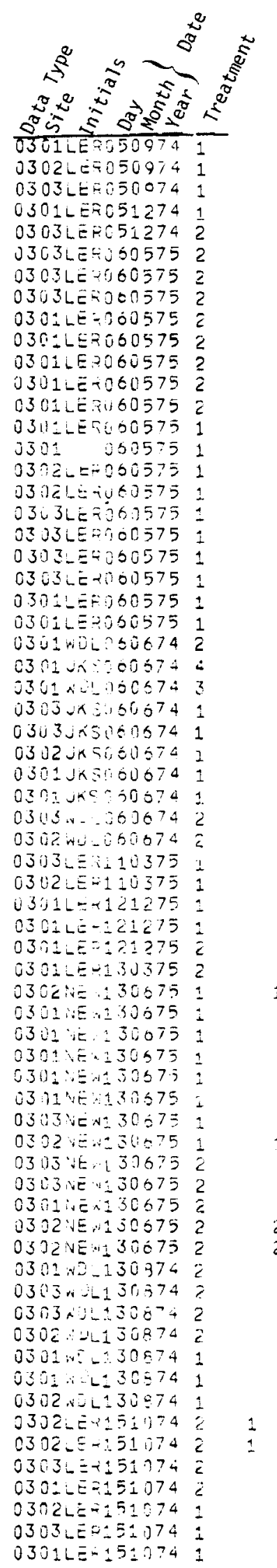

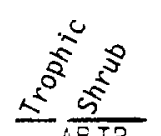

ARTP

AFTR

ART?

$\triangle R T R$

$A F T P$

$A F-R$

ART

$A F T R$

$A F T R$

$A R \div ?$

$A R^{\top} R$

$\triangle F T R$

APTR

ATT

$A R T ?$

$A F T=$

APTE

ART?

$A F T R$

$A=T$

AFT?

AसT

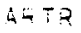

¿ AOTF

2 AT

C ATTR

AतT

AF T?

APT

敉花

AP

$\dot{A}=\vec{P}$

$A \cap-R$

AT-9

$\therefore Q T Z$

म5 TP

$A=-R$

和一

$\therefore=2$

$\therefore=T R$

$A B-P$

$4=-7$

मำ

$\therefore=5$

$\therefore ?=2$

APTF

मㄷํ으

AH

$A=T$ ?

4ล:

स०००

ब०T

सP $P$

$A F T R$

ม 2 ?

AHT?

$A=T ₹$

$2 A P T A$

$\therefore-7$

$\therefore=7$

$\therefore-2$

$\dot{s}=-7$

IE ?

$\therefore-?$

At 2

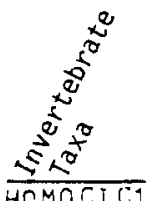

HOMOCICI

HOMOOIC1

HOMO: $: C:$

HOMOC:C:

LOMOCICI

-OMOCIC.

HOMOCICI

HOHOCI C1

HOMOCIC1

HOMOCICI

HOMOCIC:

HOMOC! C1

HOMOCICI

HOMOL"ICI

HOMOCICI

HOMOCIC1

WOMOEICI

WPMOCICI

- OMOSICI

WOMOCICA

HOMOCICA

- YMOCICI

HOMOC ICI

-C.MOC: C1

- $M$ HOCIC:

H)MOC:C1

HOMOCICI

HOMOCI CI

-OMOCIC:

- $\mathrm{MOCI} C \mathrm{C}$

HCMCICI

HOMnCICI

- TMOCIOS

HNOCI

-OMOCICA

HOMOCI L

HOMOEICI

HOMOCICA

HCMOC!C:

HOMOC? II

पOMOC! Uі

HOMOCI:

HCMOCIC:

HOMOCIOA

HOMOCICI

WnNOC ICA

WOMOC!CS

HOMOCICI

HOMOC:CI

HOMOC: C?

HOMOCICA

WOMOCI

WCMOCIC1

HOMOCICI

HOMOCICI

HOMOC:CI

HOMOCICI

-CNOCIC1

UMMOC!G:

HOMOCI CI

-CMOC:C

-OMOEIC:

HOMOSICI

-CMOCICI

r roc:C:

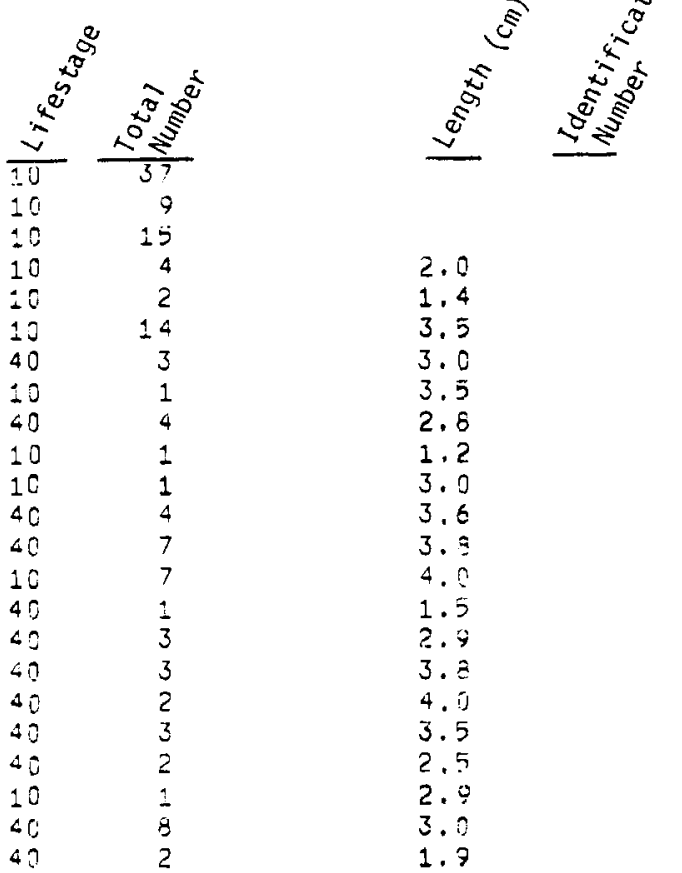

$2 \cdot 2$

1.9

2. 8

2.1

2.4

$2 \cdot 2$

6.4

2. 3

3.1

6. $\frac{1}{8}$

1.7

2. 0

2.3

6.0

2.. 2

2.3

1.5

1.8

2. 1

3.9

2. 3

1.3

2.0

3.5

2.3

A. 9 


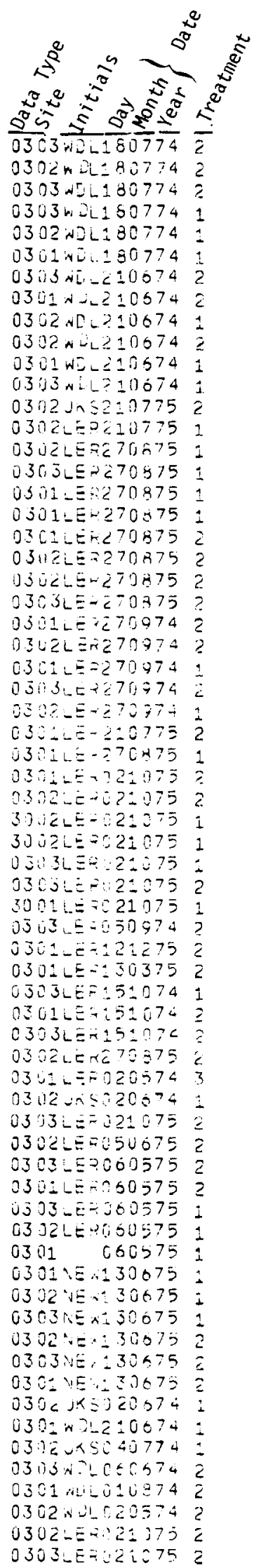

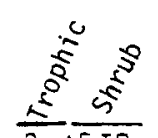

2 AFTR
2 AFTR

2 AFT

$2 \quad A=T$

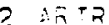

$2 \quad \therefore=+Q$

$\therefore \because T 2$

$? A R T R$

¿ิ?

A₹?

$A=T 2$

$2 \triangle Q T P$

$\therefore R T P$

든

ARTF

厶A TO

IF TA

APT?

Af

AFT

다?

$A=-5$

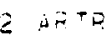

मेन स

2 A保?

IFT

$\therefore=T Q$

มं-

Aि

A $F-Z$

$\dot{4}=T$

$\therefore=+?$

$\rightarrow F=$

$\therefore A=0$

$127=$

$1 \%-7$

$\therefore+F$

A 12

Gरण

$A \vec{A}^{\top}$ ?

$\therefore=-5$

aㄱ $=$

$\therefore=T=$

$\because$ in

少标

is $=15$

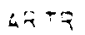

$A F-R$

$\therefore:-2$

$A=T A$

$\therefore=T 2$

मिन

$A=T R$

If

AF $=$ ?

$\therefore=-?$

$\therefore$ सर

AETA

$\dot{i}=-7$

A $=50$

$3:=-7$

? i $2=2$

$3: 4$

$\therefore \because-5$

구

$2-i$
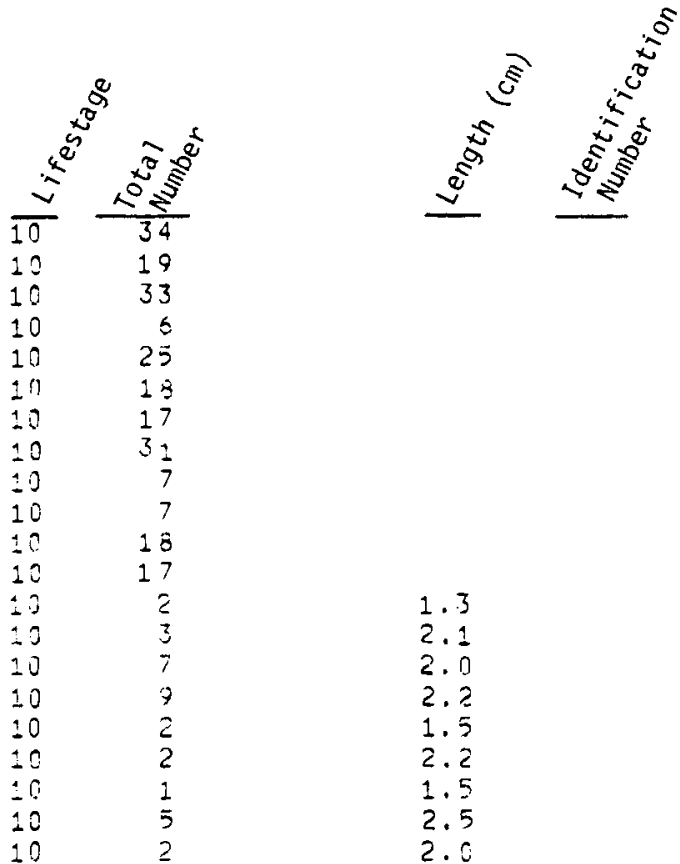

$1 \cdot 3$

2. 1

2. 0

2. 2

1.5

2. 2

1.5

2. 5

2. 0

2. 1

1. 3

2. 0

2.

1.7

1.9

5.15

4. 3

1. 4

$1 \cdot 3$

1. 0

1.5

1.4

1.5

חMOCA -OMOCETH

- ?MJ

LMOCHTH

WONOSATH

MOMOSBPTH

- AICCDTH

HONOSETH

WCMOCETH

-NMCPSYL

UTMOESYL

LOMJPSYL

-ONOFSYL

- $M Y O F S Y$ -

HOMOFSYL

- $2 M D F S Y L$

WOHOFSYL

MOMOOSYL

HCMOFSYL

- OMOFSYL

HMOFS VL

-OMOESYL

AOMFSYL

- OMOOSYL

-

-VMEUF:

- $Y M \equiv \Xi E T h$

- $v$ v

LV

- $\times$ WE $=20$

LY WESTIC

ค䟚的小
1.5

1. 5

2. 2

1.7

2.2

1. 5

1.?

1.5

74014

1.5

1. 3

1.5

1. 6

1.3

1. 2

1. 2

1.5

1.6

1,3

1. 5

2.

3.0

74334
A. 10 


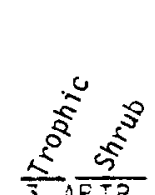

3 AET?
ART?

उ $\triangle F T R$

3 ATTR

LQTR

AFTR

3 ARTR

3 ARTP

3 AFT?

O $\triangle A T P$

2 AFTR

3 APTP

ARTR

3 ARTR

ARTA

$3 A R T R$

3 ACTR

3 ATTR

3 AFTR

3 APTR

AR TR

AFTR

3 ARTT

3 ARTF

3 AFTE

AF TR

AFTR

$A R T P$

$\Delta F=?$

3 APT7

$A R: Z$

DOT

AFTR

ARTR

$A E T P$

मर

$A=\div Q$

ARTR

ARTP

$34 \bar{\pi} 7$

$3 A F^{-}$

$\checkmark \quad \triangle K T=$

$A E T R$

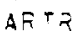

$A A^{-Q}$

IFTT

$A=T ?$

AFI TR

3 मसं

AP:?

$\angle \quad A P T P$

$\triangle P T$ T

AET?

$A F T R$

$32=T R$

5 AF

8 AनT?

7 A

3 A $P$ ?

a $4 F-P$

$4 R T 2$
$\dot{A}=-$

i.

in

DFTF

TAFT

$4 A+?$

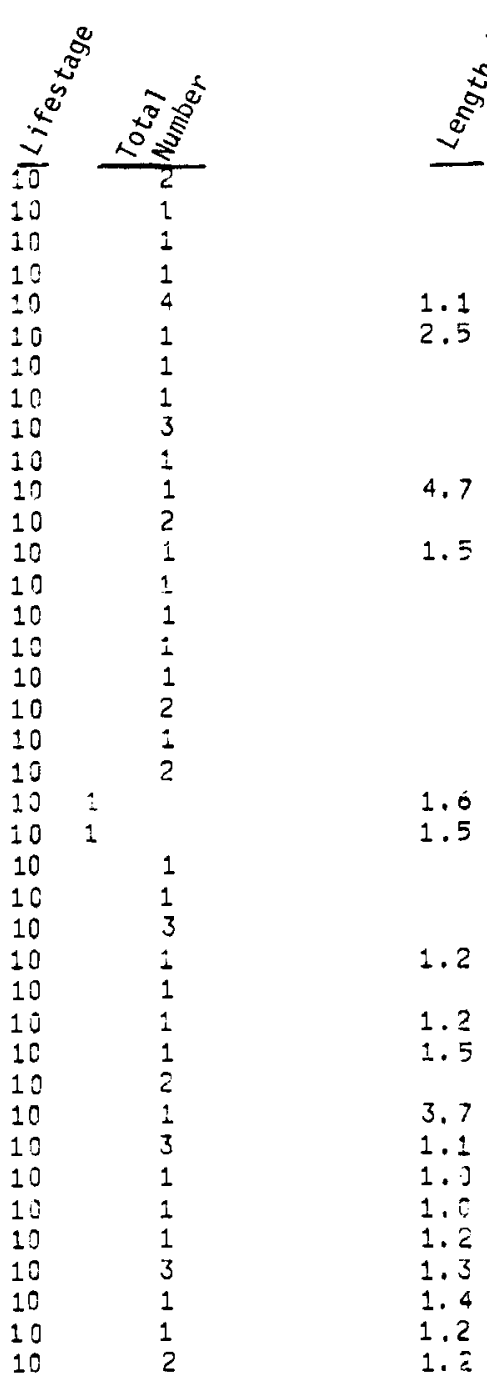

HYMECHAL

AYMECHAL

WYMECHAL

HYMECHAL

HY YECHAL

HYMECHAL

HYMECHAL

YMECHAL

HYMECHAL

YMEGTAL

GVMECHAL

HYMEC AL

UYMECHAL

TYMECHAL

YMEEHAL

HYME CHAL

WYME CHAL

HYMECHAL

HYMECHAL

TYMECHAL

HYMECHAL

LYMECHAL

HYMECHAL

MYMECHAL

HYMECHAL

HYME CHAL

WYMEOHAL

HYMECHAL

HYMECHRY

HYMECYMI

HYMECYN I

HYMECYAI

HYMEELLO

HYMEEURYY

HYMECLRY

WYMEFIGI

HYMEF ORM

WYMETCR

WYMEF OFM

WYHEFOF

-YMEFCFM

-VMEFOFM

HVUEFORM

AVMEE ORM

- YMEFRAM

HYYEF ORM $\frac{1.1}{2.5}$

4.7

.5

1.0

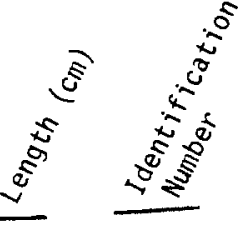

.2

3.7

1.7

1. 4

1. 6

4.2

4.0

2. 0

0.9

$0 . E$

1.4

3.7

4.0

A.11 


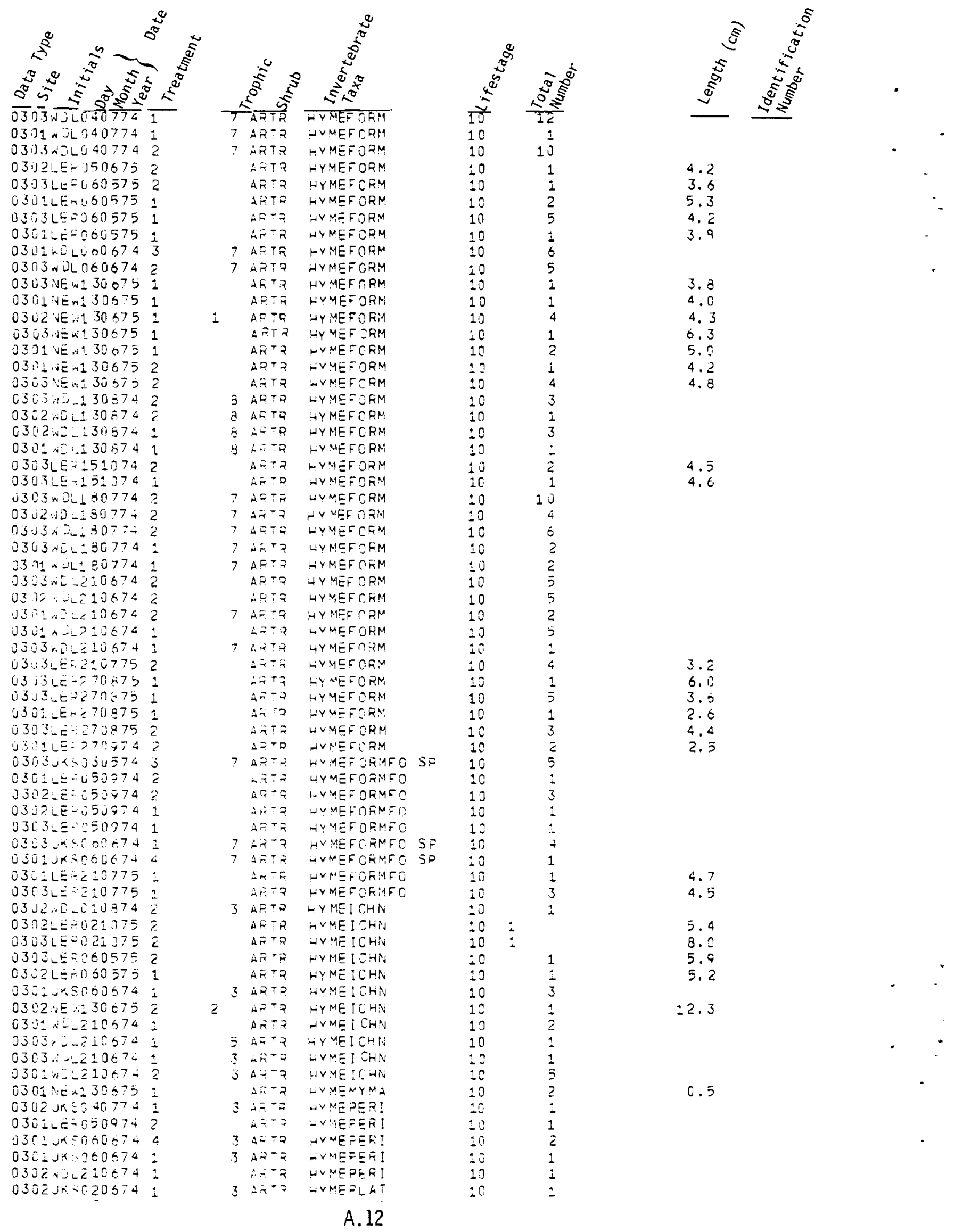




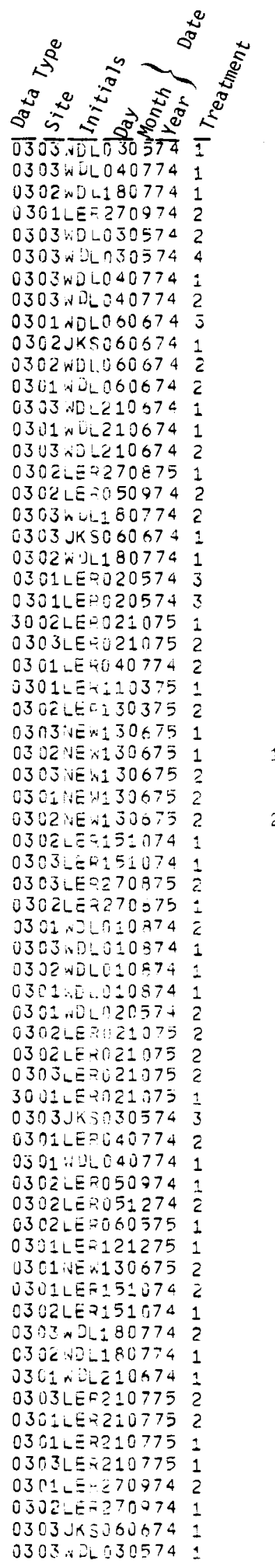
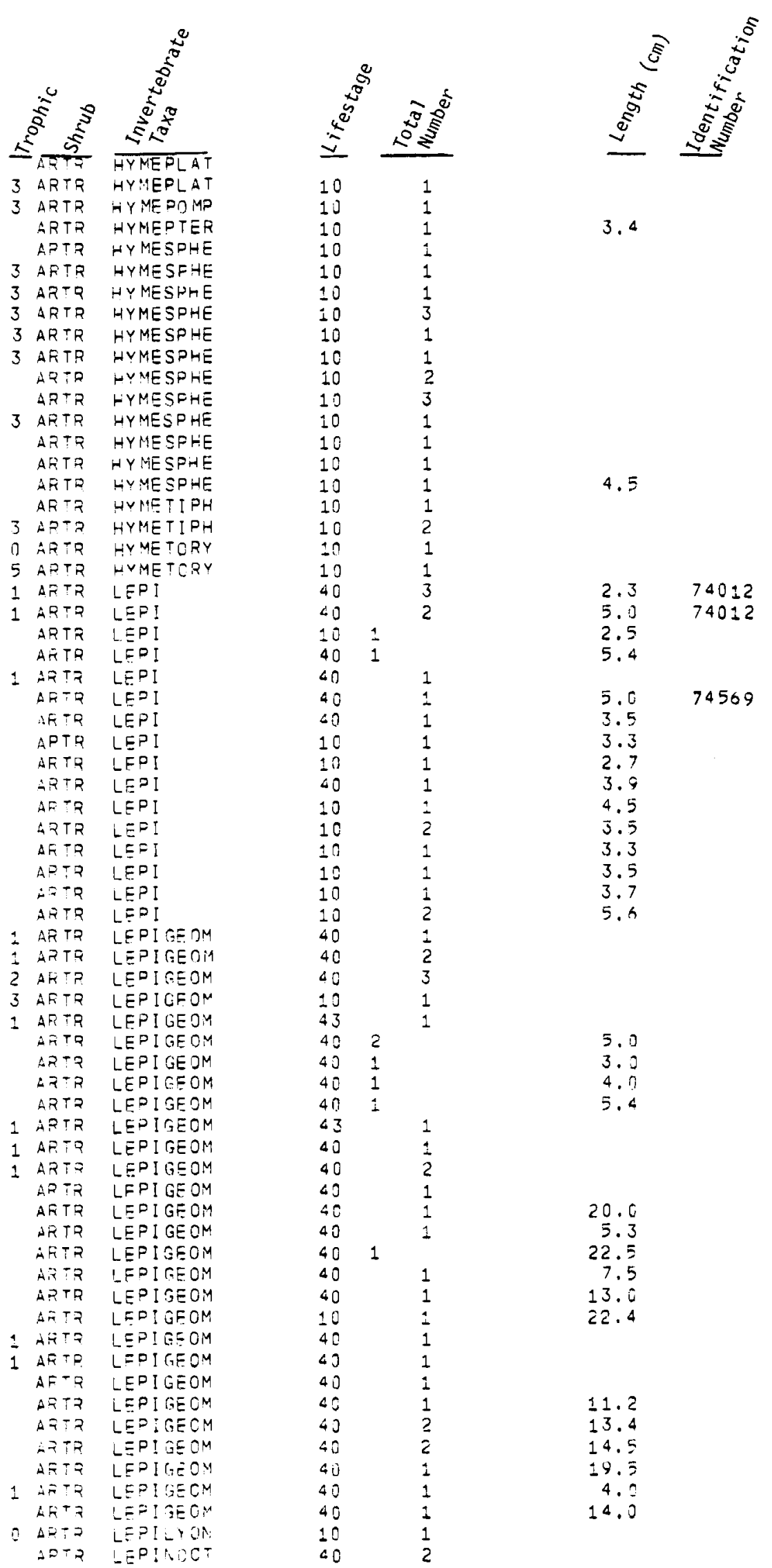

4.5

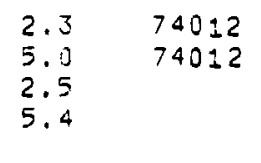

$5.0 \quad 74569$

3.5

3.3

2.7

3.9

4.5

3.5

3.3

3.5

3.7

5.6

5.0

3.0

4.9

5.4

20.0

5.3

22.5

7.5

13.0

22.4

11.2

13.4

14.5

19.5

4.0

14.0

A. 13 


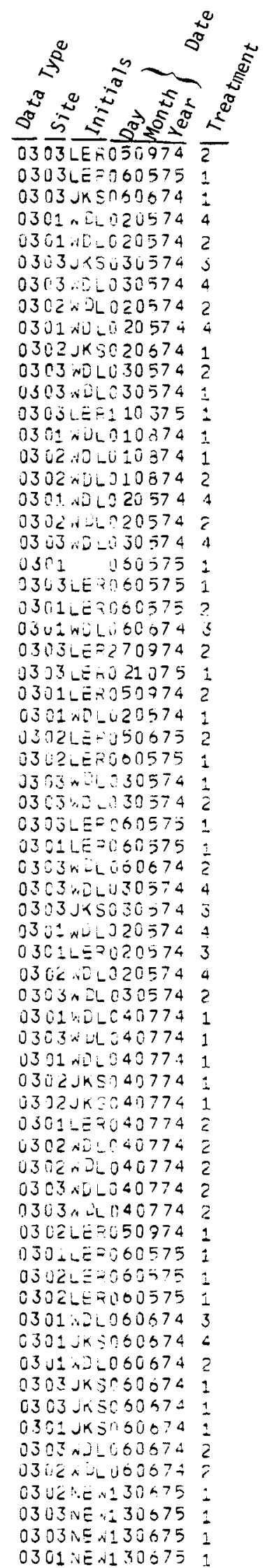

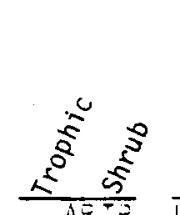

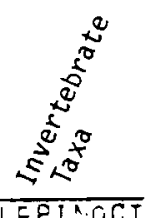

$A R T P$

$1 \quad \triangle F T A$

1 मㅈ?

1 मरं

1 Aरा

$1 A D T$ T

AF

AT

1 म $F T$ T

AR 7

IPT

AF $R$

$5 \triangle R T R$

5 ATT?

5 क 5 T

$5 \quad A 2 T R$

AET

5 AT TR

Aर TF

ART

$\therefore P T A$

5 APT

Aए

AरT

A०

5 ART?

$A P+2$

$A=-5$

$\triangle P=?$

गA

AFT?

AีT

5 - 977

5 AिTन

5 Aㄴ?

- माने

$14=T=$

AP

AFT

1 ค $\div$ -

1 मसार

मा. -8

1 म $\dot{\alpha} T$

I $\triangle$ IT

AFT?

I DETP

1 A?T?

$1 \leq R T R$

I $\angle F T R$

APT?

ARTO

ATT?

AFT?

I ARTR

1 I TR

AT?

1 A $\bar{K} T$

I AITR

I AP.TE

$\perp A F T$

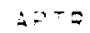

1

LEPIATCCT

EPINOCT

LEPINOCT

EP IPLUT

LEPIFLUT

EPIPLUT

$L E P I F L U T$

LEIPYRA

EPI PYRA

LEPIFYRA

LEP IFYRA

EPIFYRA

LCPIFYRA

NEURCHRY

VE URCHRY

VE UR SHRY

EURCHRY

$V=U R$ Cit RY

IEURCHFY

EURCHRY

- EURCURY

$\therefore E \cup R C H A Y$

NEURCHRY

VEURTEME

SE URHEME

NEURHEME

NELFRAFH

IEURRAPH

A.EURGAFH

NEUP PAPH

YEURFAPH

ORTHACRI

FTHACR I

CF THA AR!

CRTHA CR I

CF THACRI

OETHACRI

OF THACRI

SATHACRI

ODTHACRI

CDTHACRI

OFTHACRI

ORTHACE!

CRTHACRI

OETHAOR!

CQTHACRI

OFTHACR!

OETHACRI

ORTHACRI

OPTHACRI

OFTHALE!

ORTHACER

ORTHACRI

$C=T H A C E I$

हลТҢ CQI

DETHACP!

$0=T H A C R$ !

FTTHACFI

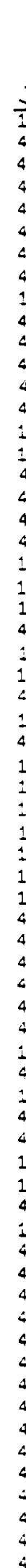

$\infty^{\infty}$

IEURCHRY

VEUFCHFYCH IA

EURCHRYCH DA

VFURFAPHAG $\partial$ !

EUREAPHAG 3 I

$C=T H A C F ;$

OETHAOZ!

$C=T H A C R$ !

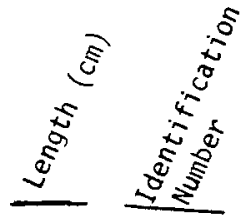

25.2

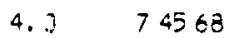

2. 5

4.0

10.5

4.7

2.4

3. 0

9.4

4.7

4.4

4.5
5.3

6.9

3.3

14.9

7.3 


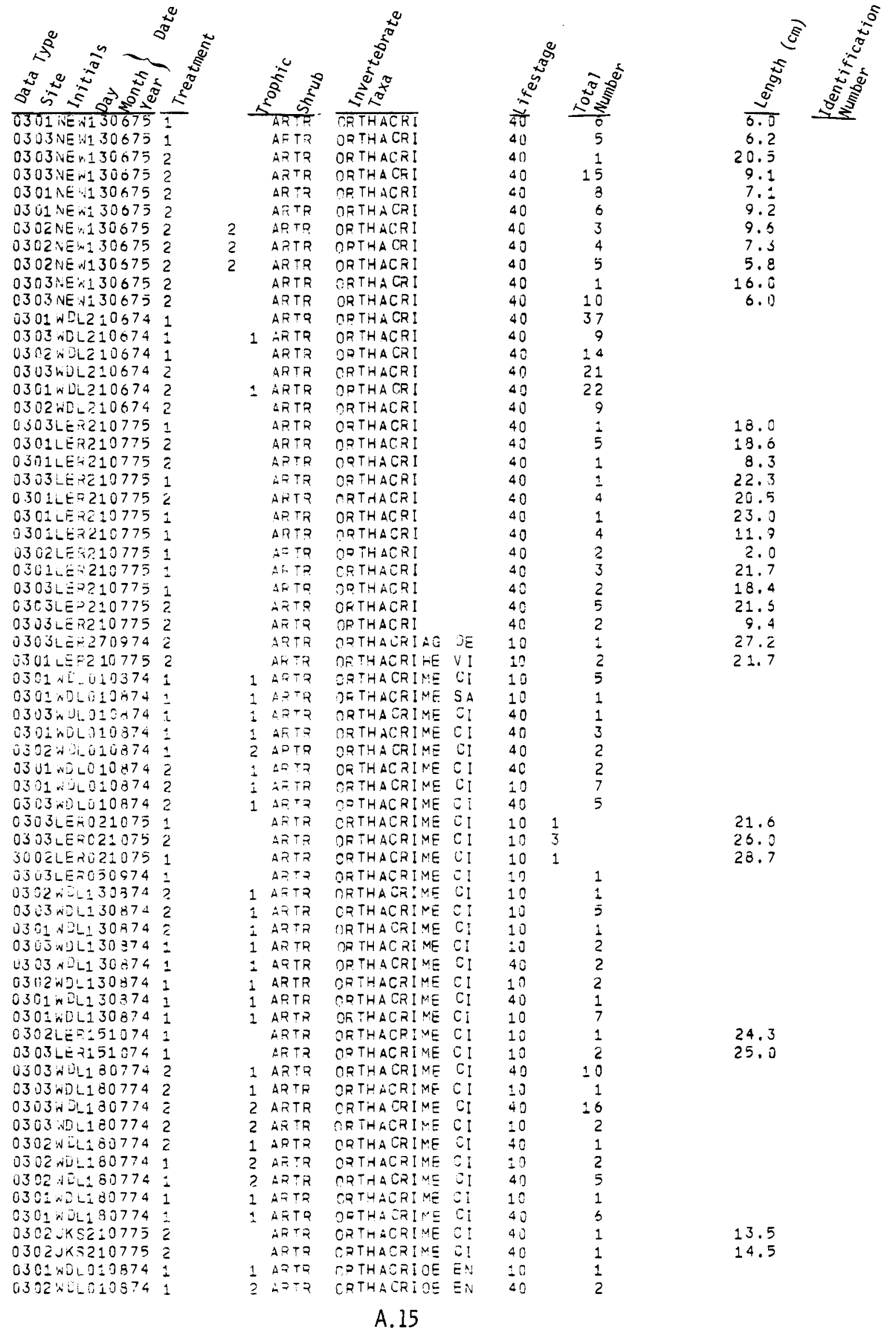



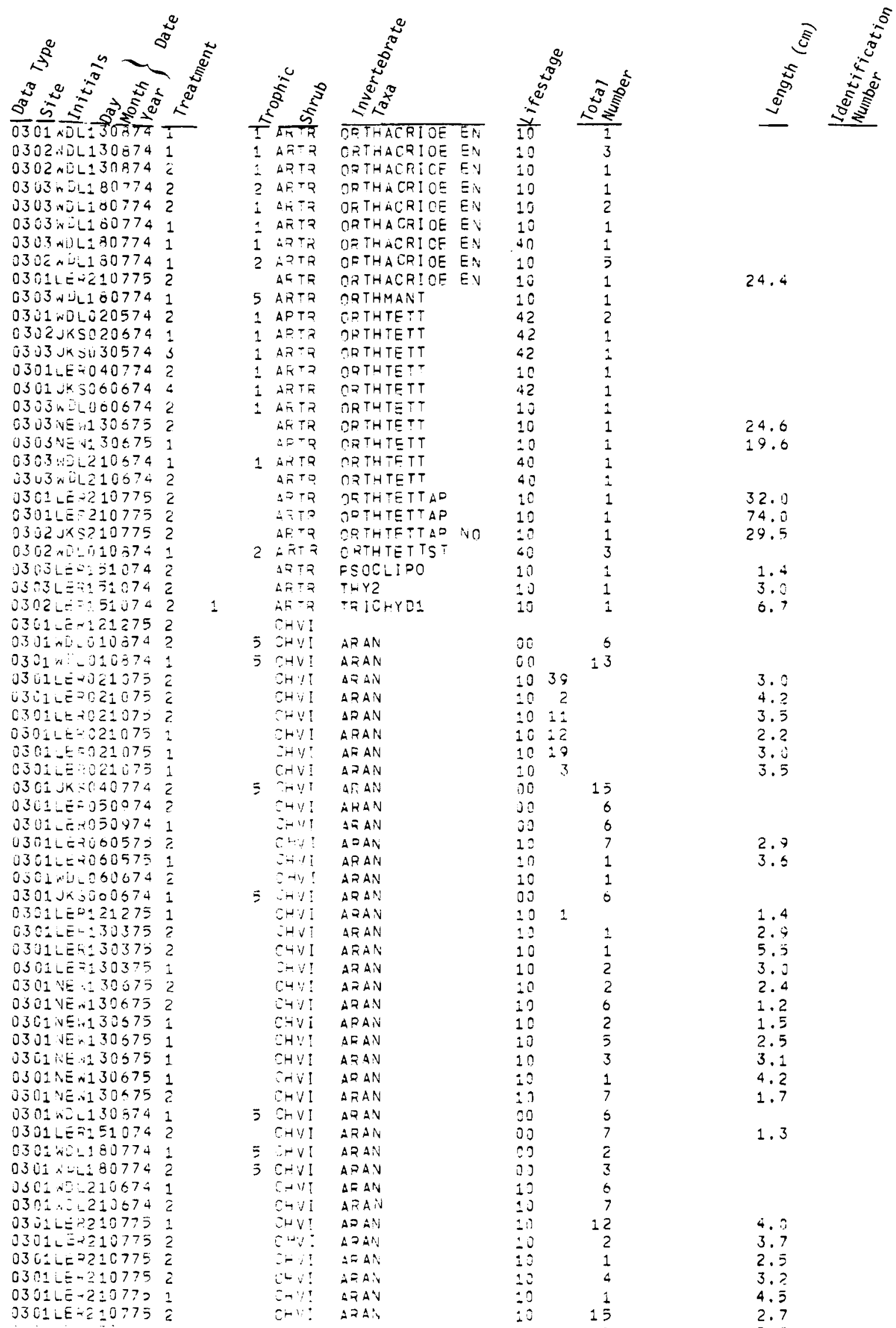

24.4

24.6

19.0

32.0

74.0

29.5

1.4

3.0

6. 7

$\begin{array}{rrrr}00 & & 5 & \\ 00 & & 13 & \\ 10 & 39 & & 3.0 \\ 10 & 2 & & 4.2 \\ 10 & 11 & & 3.5 \\ 10 & 22 & & 2.2 \\ 10 & 10 & & 3.0 \\ 10 & 3 & & 3.5\end{array}$

10

30

งว

12

10

10

101

12

10

10

10

19

10

10

10

10

$\therefore .1$

ด.

03

(อ)

1)

10

$\pm 1$

13

12

15

3.5

2.9

3.6

1.4

2.9

5.5

3. 0

2. 4

1.2

1.5

2.5

3.1

4.2

1.7

1.3

A. 16

4.5
3.7
2.5
3.2
4.5
2.7 


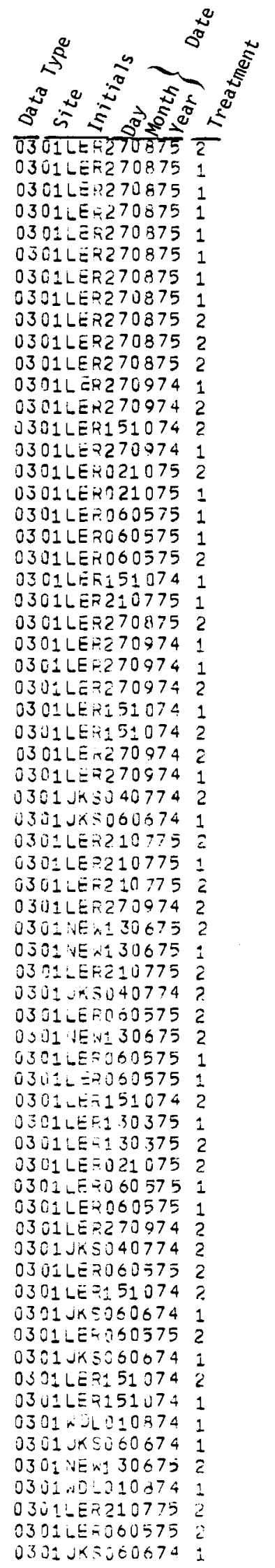

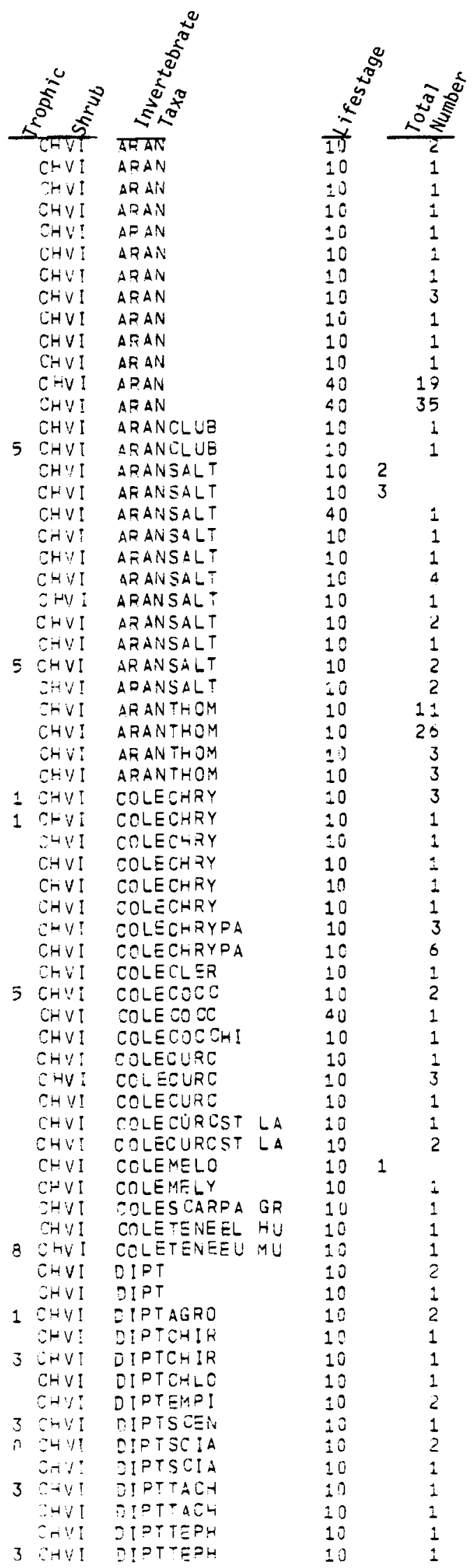

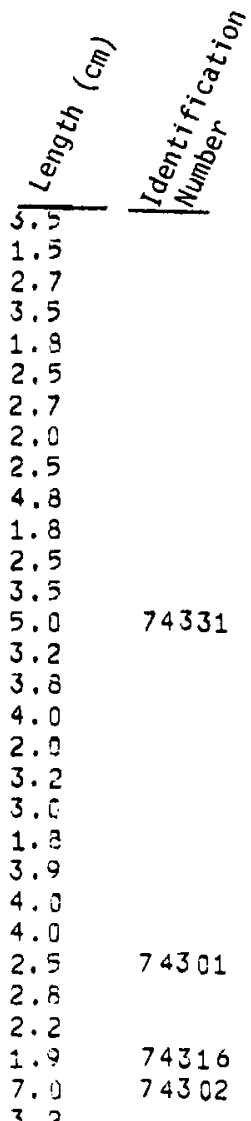

3.?

6.3

2.4

2. 8

3.0

1. 7

2.8

3. 17

1.0

4.2

5.4

4.7

2.7

5.2

4.8

10.0

2.6

16.2

17.0

2.0

1.7

74330

2.2

4. ن

1. 1

74308

2.8

6.0

2.7 


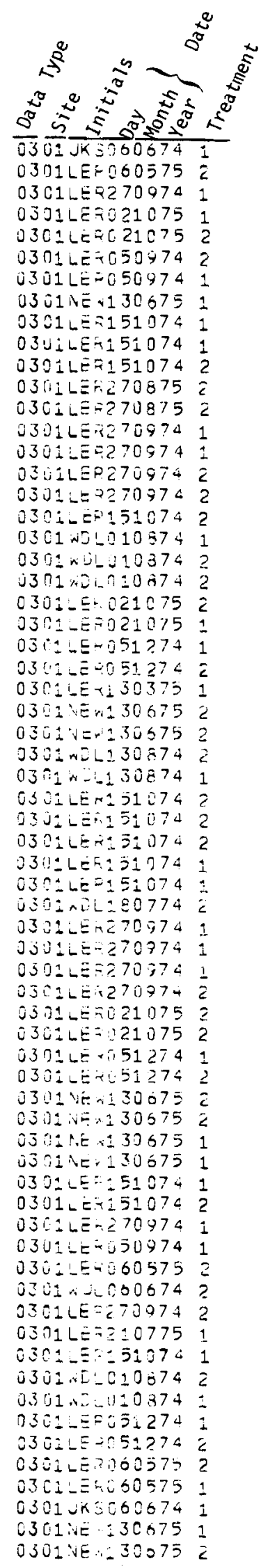

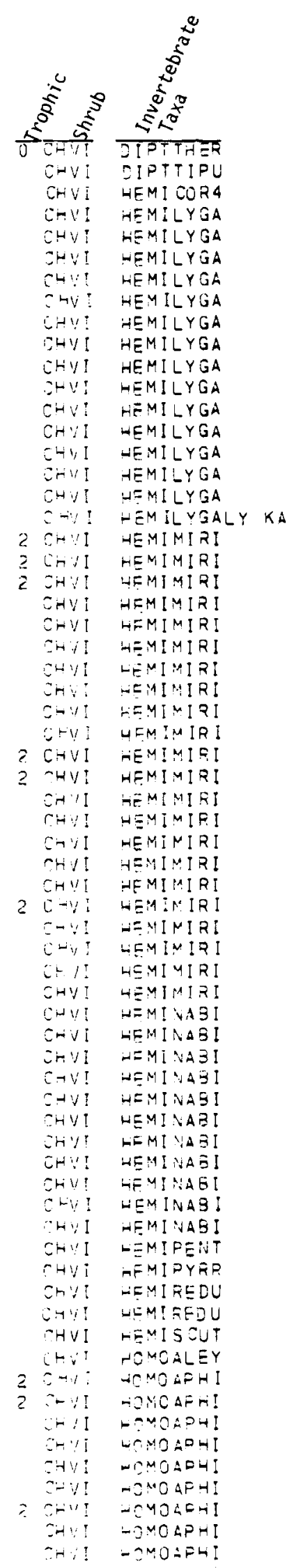

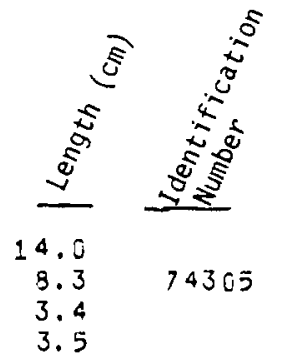

2.1

9.1

3.2

2.0

5.3

3.5

9.4

3. 3

3.2

3.2

10.2

3.7

5.3

5.2

4. 6

4. 8

2.9

3.4

4.3

3.5

4.6

3.6

5. 3

3.2

3.0

5.0

8. 5

6.8

6.3

6.?

6.5

4.6

4.3

6.0

6.5

6.4

6.4

3.

13.0

5.0

0.7

74310

1.5

1.0

$1 . ?$

1.5

1.6

1.8

74317

74319

74412

(20)

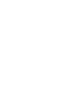

A. 18 


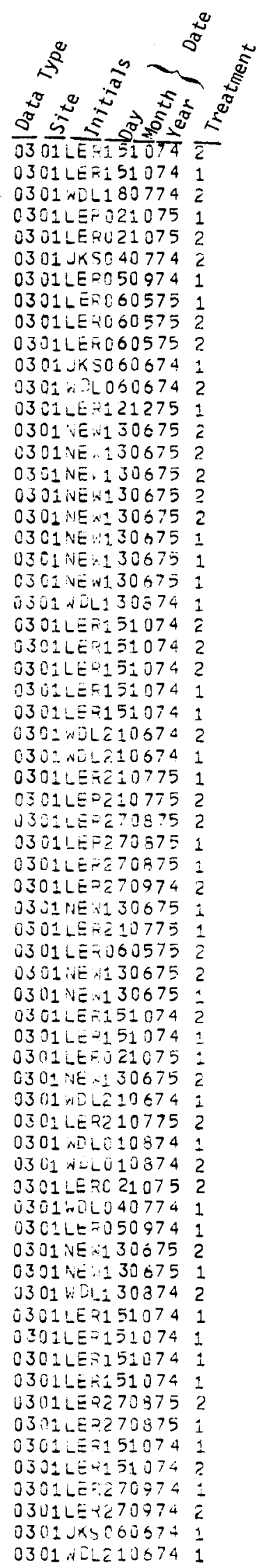

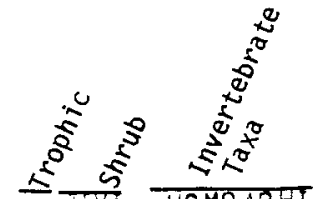

InVI HOMOAPH

2 CHVI HOMOAPHI

CHV! HOMOCICI

CHVI HOMOCICI

2 CHVI HOMOCIC1

CHVI HOMOCI CI

CHVI HOMOCIC:

CHVI HOMOCICI

CHVI HOMOCIC:

2 CHVI HOMOCICI

CHVI HOMOC!CI

CHVI HOMOCI CI

CHVI HOMOCICI

SHVI HOMOCIC:

CHV! HOMOCIC1

CHVI HOMOCICI

CHVI HOMOCICI

CHV! HOMOCICI

CHVI HOMOCICI

CHVI HOMOCICI

2 CHYI HOMOCICI

CHVI HOMOCI CI

CHVI HOMOCICI

CHVI HOMOCI C1

CHVI HOMOCICI

CHVi HOMOCI

CHVI HOMOOICI

CHVI HOMOCICI

CHVI HOMOCICI

$\mathrm{CH} !$ HOMOCI CI

CHiv! HOMOCIC:

OHVI HOMOC:CA

EHV! HOMOCICI

EHVI HOMOCICI

CHVI HOMOJICT

CHVI HOMODICT

CHVI HOMOPSYL

CHVI HOMOPSYL

CHYI HOMOPSYL

CHVI HOMOPSYL

CHVI HOMOPSYL

EHVE HYMEEFAC

CHUI GYMEBRAD

CHII HYMEBRAC

CHVI HYMEERAC

3 CHVI HYMECHAL

3 GHVI HYMECHAL

CHV! WYMECHAL

3 CHV! HYMECHAL

CHVI HYMECHAL

CHVI HYMECHAL

CHVI WYMECHAL

3 CHVI HYMECHAL

EHYI HYMECHAL

CHVI HYMECHAL

CHVI HYMECHAL

CHVI HYMECHAL

CHVI HVMECHAL

CHVI HYMECHAL

CHVI WYMEEYMI

CHYI GYMECYNI

THUI WYMEEYNI

EHI HUYECYN?

0 EH. I HYMEZEYI

CHY! HVMEENGY

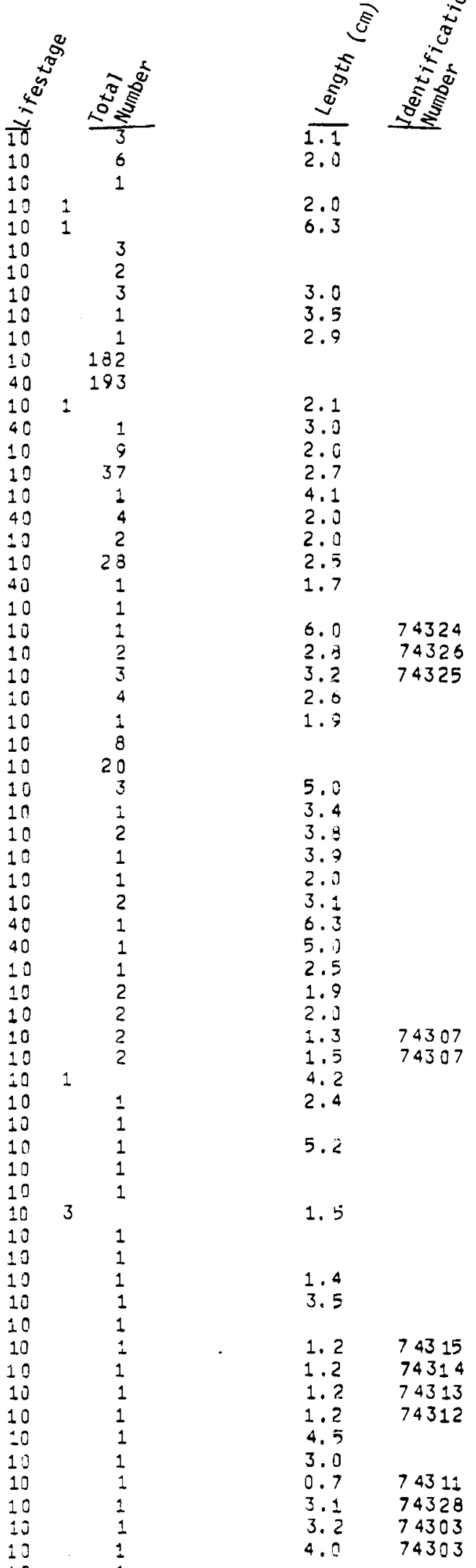




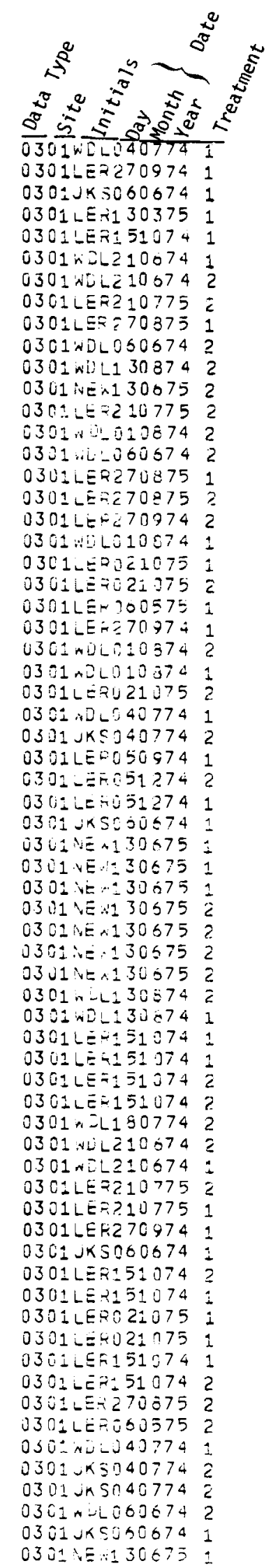

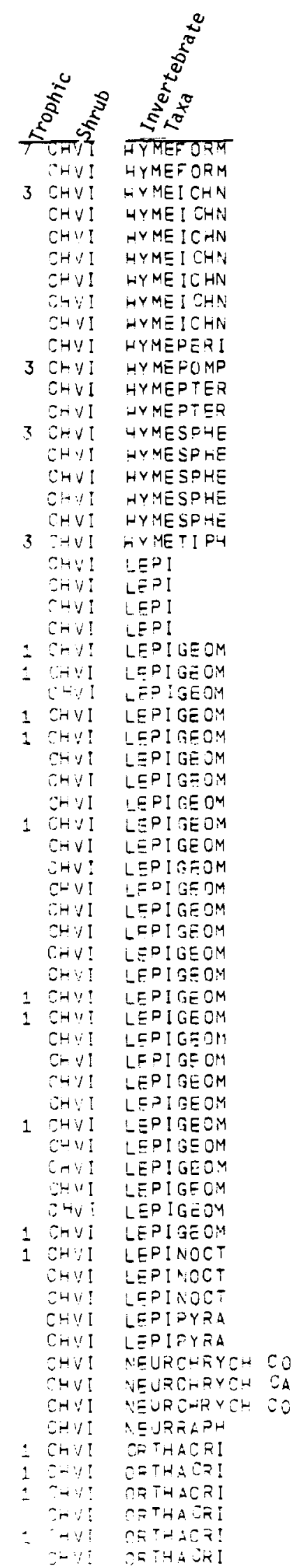

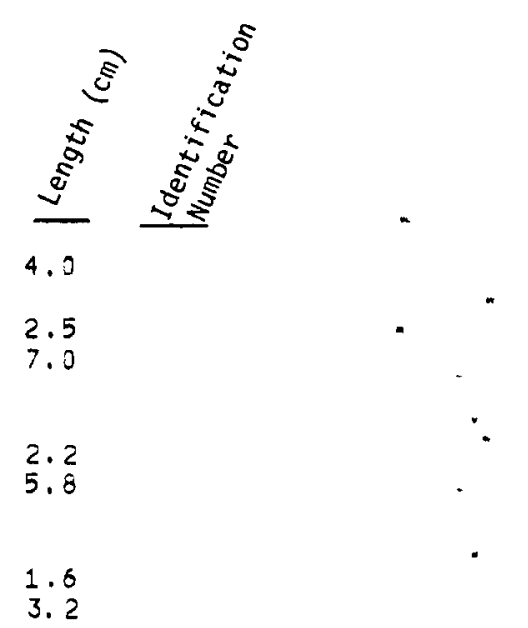

1.5

12.4

11.4

8.3

6.0

6.4

10.5

10.0

11.0

14.8

12.2

10.2

25.3

16.6

14.2

6.4

11.2

$3 \cdot 0$

16.7

17.5

74333

9.5

10.0

13.0

11.0

$\begin{array}{ll}3.6 & 74332\end{array}$

14.3

5.6

8.3

8.5

9.7

8. 7

8.0 

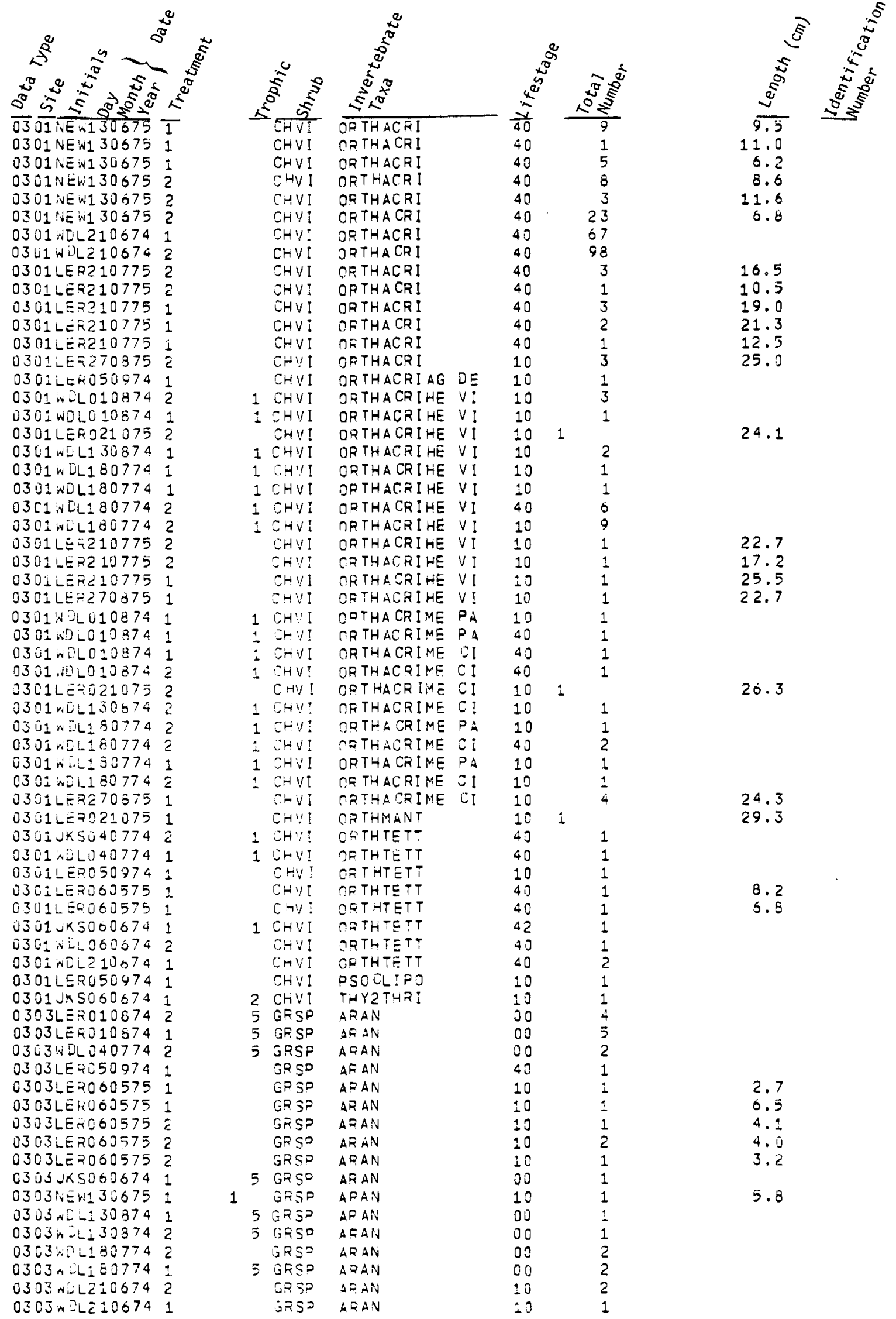

16.5

10.5

19.0

21.3

12.5

25.0

24.1

22.7

17.2

25.5

22.7

OOTHACRIME PA

CRTHACRIME PA ORTHACQIME C ORTHACRIME C ORTHACRIME PA ORTHACRIME CI ORTHACRIME PA OFTHMLNT

24.3

29.3

1

26.3

8.2

5.8

2.7

6.5

4.1

4.0

3.2

5.8

A. 21 


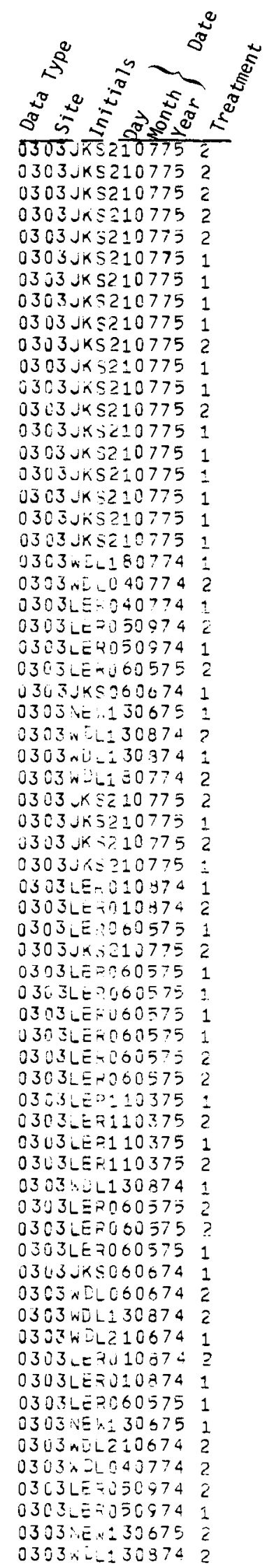

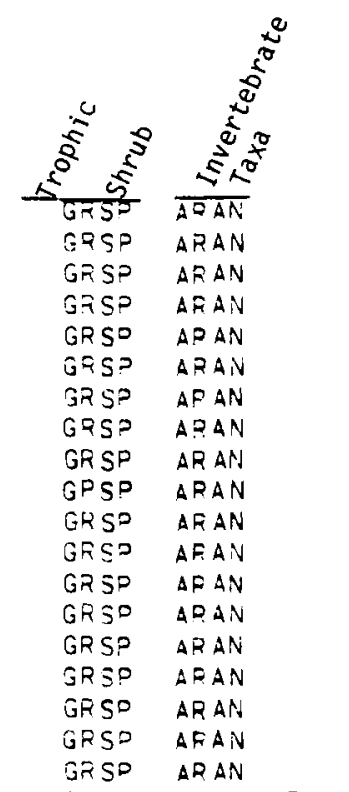

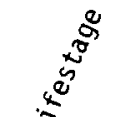

1 GPSP

1 TतS

1 URSO

GRS?

GRSP

GRSP

1 GRSP

1 JRS?

1 GRSP

1 GRT

cas?

jo 20

GRSP

GS SP

ERSO

1 GRSP

1 GRS

GRSF

BरT?

GFSP

GFSD

jos?

GRSO

GRL

GRSO

GŔ 50

GRED

GPSP

GRS =

1 SRSP

GRSP

SRSP

GRSP

1 GRSD

GRSD

GRSP

GRS=

GRSO

GPSO

Cㄷ.ร2

gas?

3 हरㄱ

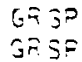

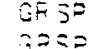

COLECARA

COLECHRY

COLECHRY

COLECHQY

COLECHRY

COLECHRY

COLECHRY

COLECHRY

COLECHRY

COLECHRY

COLECHRY

COLE CHRY

COLECHRY

COLECHEYMC

COLECHRYMO

CDLECHEYMO

COLECLER

COLECURC

OOLECURC

COLEZURC

COLECURC

COLECURC

COLEUURC

COLECURCCE Aं COLECURCCE AF CCLECURCST LA COLECURCST LA

COLEMELO

COLENELY

COLENELY

COLEMELY

OI P AGRO

DIPTEOMB

IIPTHCME

J?PT SOMB

TPTEOMGMY

DIPTEOMEM

DIPTCHIR

IIPTCHIR

IPTCRLO

OIPTS CEN

ziotscen

-DPTSGEN

OT OT SEEV

IPTS CE?

A. 22
COLECHRY

COLECHFY

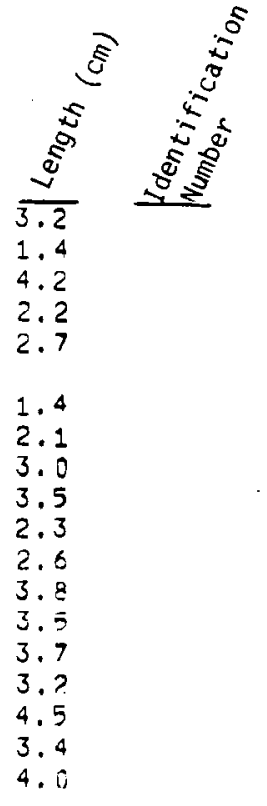

4.0

3. 4

3.0

3. 4

3.

3.2

3. ?

3.5

4.9

4.2

6.1

2.5

3. 0

2. 8

4.7

3.2

2. 8

3.4

1.7

2.7

4. 1 

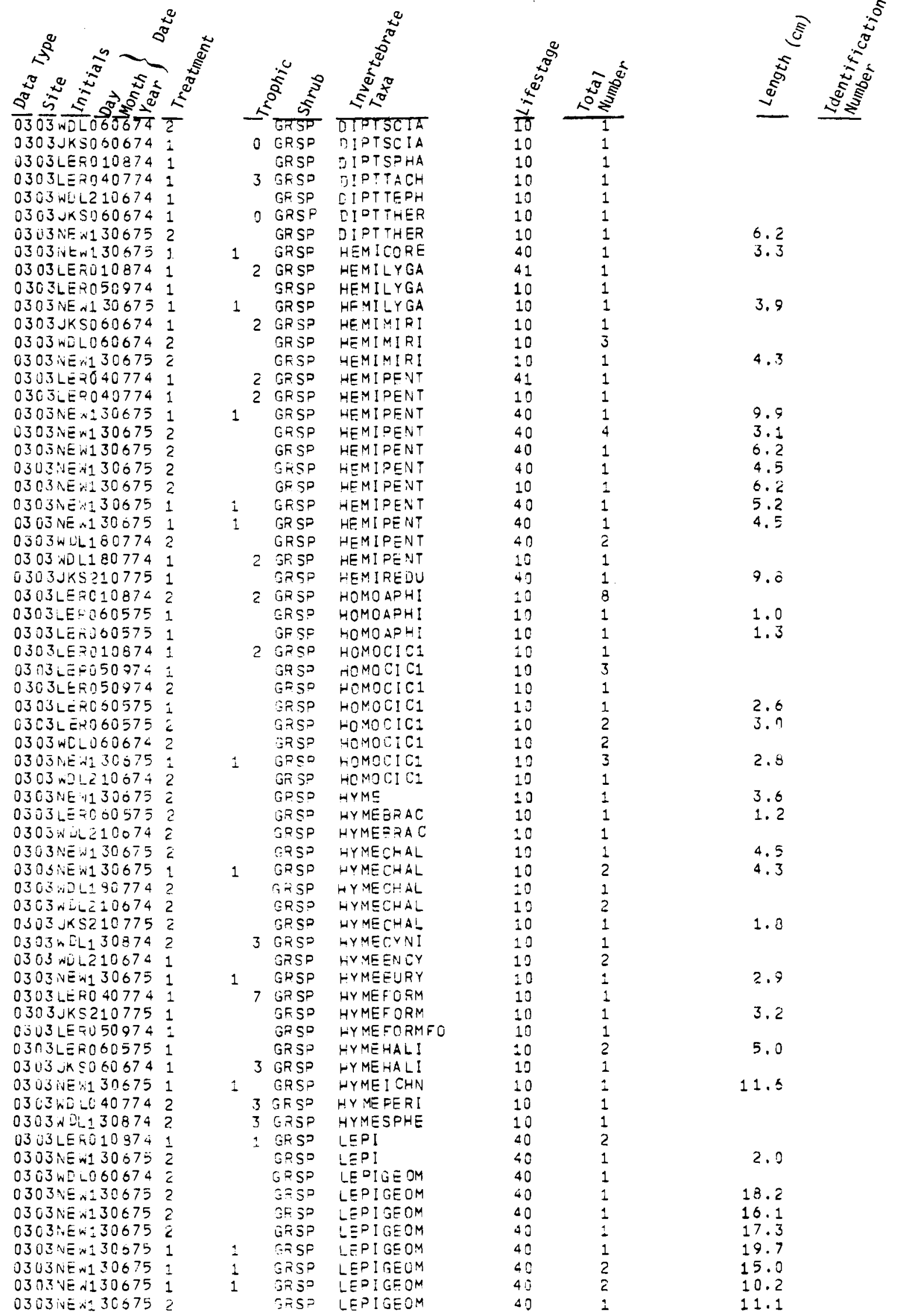

6.2
3.3
3.9
4.3
9.9
3.1
6.2
4.5
6.2
5.2
4.5

9.0

1.0

1.3

2.6

3.7

2.8

3.6

1. 2

4.5

4.3

1.3

2.9

3.2

5.0

11.5

2.0

18.2

16.1

17.3

19.7

15.0

10.2

11.1

A. 23 


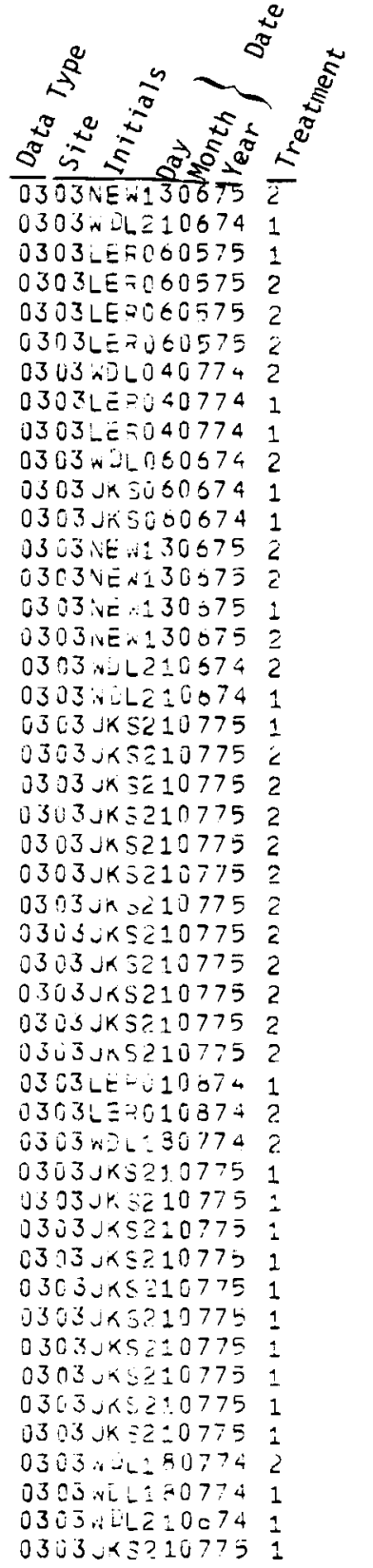

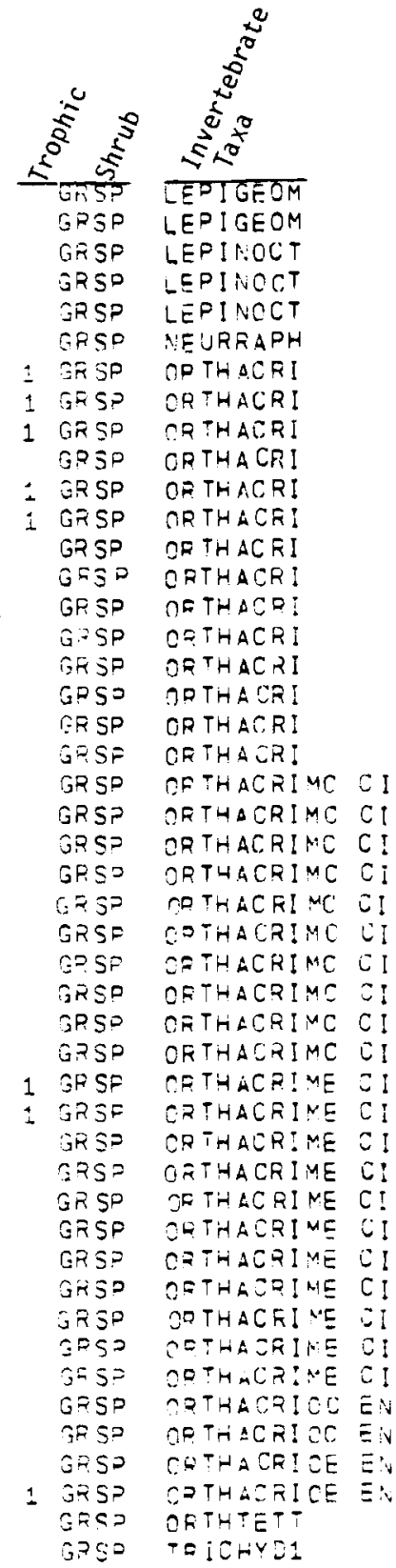

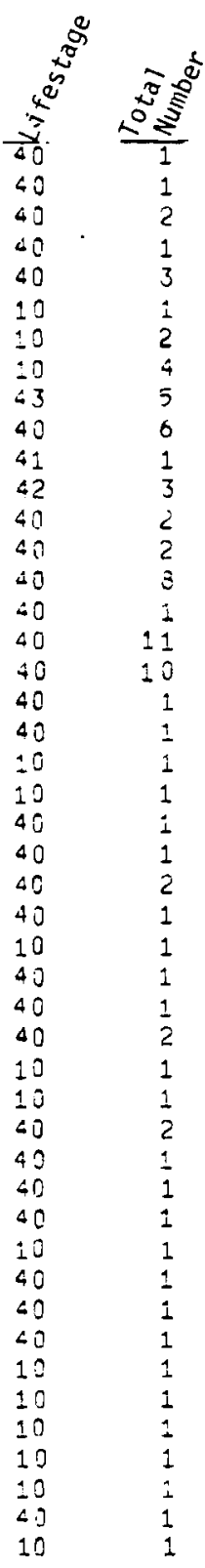

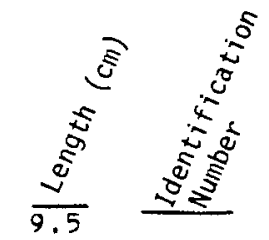

14.1
24.9
14.2
7.1

10.2

8.0

8. 0

11.2

14.4

19.2

23.4

24.9

12.0

11.0

15.8

19.7

22.6

21.7

19.3

17.7

16.3

12.3

20. 0

22.4

20.5

18.9

16.9

22.0

22.3

24.7

0.5 


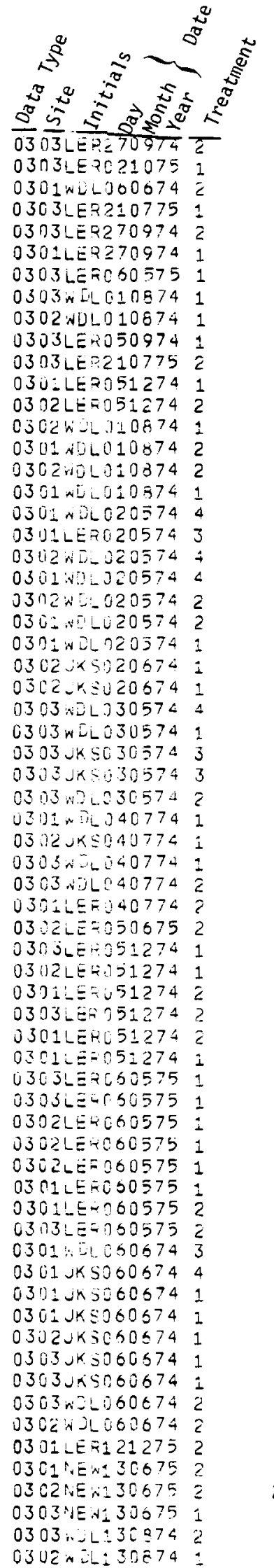

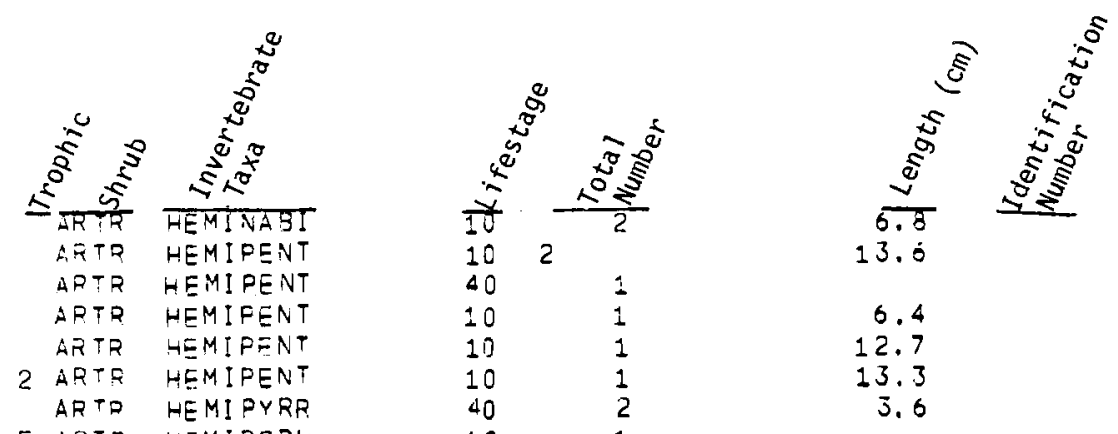

5 ARTR HEMIREDU

5 ARTR HEMIREDU

ARTR HEMISCUT

ARTR HEMISCUT

ARTR HOMO

ARTR HOMO

2 ARTA HOMDAFHI

2 ARTR HOMOAPHI

2 ARTR HOMOAPHI

2 ARTR HOMOAPHI

2 ARTR HOMOAPHI

2 ARTR HOMOAFHI

ARTR HOMOAPHI

ARTR HOMOAPHI

ARTR HOMOAPH:

2 ARTR HOMOAPHI

2 ARTR HOMOAPH!

2 AF $P$ HOMOARHI

2 ARTR HOMOAPHI

2 AFIR HOMOAPH?

APTP HOMOAFHI

2 AFTR HOMOAPHI

2 ARTF HCMOAPHI

ARTR HOHOAPHI

2 ARTP HOMOAFHI

2 MRTR HOMOAFHI

2 AFTR HOMOAPHI

2 ARTP HOMOAPHI

2 ARTR HOMOAOH

ARTR HCMOAPH

ARTP LOMOAPH

ARTR HOMOAPHI

ARTR HOMOAPHI

ARTP HOMOAFH

ARTR HOMOAPHI

$\triangle R T R$ HOMOAPH

APTR HOMOAFH

ARTE HOMOAPH:

ARTR HOMOAPH

ARTR HOMOAPHI

ARTR HOMOAFH

ARTR HOMOAPHI

ARTR HOMOAPHI

AFTR LUMOAPH

2 ARTR HOMOAFH

2 ARTP HOMOAPHI

2 ARTR HOMOADHI

2 ARTR HCMOAPHI

2 ARTR hOMOARHI

2 ARTR HOMOAFHI

2 ARTP HOMOAPHI

2 AFTR HCMOAPH!

AETR MCMOAFH

ARTP HOMOAPHI

AETP HOMOAPH

$2 \quad A F+2$

HOMOAPHI

ARTR HCMOAPHI

2 AETR HOMOLPH

2 ARTD HOMOAFHI
6.4

0.8

1.2

1.2
1.0

1.0

1.3

1.0

1.0

1.3

0.9

1.3

1.1

1.0

0.5

0.9

1.4

$1 . ?$

1.2

1. 5

1. 1

i. 3

A. 25 
NOTES

${ }^{1}$ See Figure 2 for a list of trophic levels.

${ }^{2}$ ARTR = sagebrush; CHVI = rabbitbrush; GRSP = hopsage.

${ }^{3}$ Invertebrate taxa codes consist of first four letters of order and family names.

${ }^{4}$ See Figure 2 for a list of lifestage codes.

${ }^{5}$ The identification number was used during sample processing. 


\section{DISTRIBUTION}

No. of

Copies

OFFSITE

A. A. Churm

DOE Chicago Patent Attorney

9800 South Cass Avenue

Argonne, IL 60439

(27) DOE Technical Information Center

Department of Energy

R. C. Clusen

Ass istant Secretary for

Environment

Washington, DC 20545

P. B. Dunaway

Nevada Operations Office

P.0. Box 14100

Las Vegas, NV 89114

J. L. Liverman

Deputy Assistant Secretary for Environment

Washington, DC 20545

0. D. Markham

Radiological and Environmental Sciences

Laboratory

DOE Idaho Operations Office

550 Second Street

Idaho Falls, ID 83401

S. Meyers

DOE Office of Nuclear Waste Management

Washington, DC 20545
No. of

Copies

\section{OFFSITE}

S. I. Auerbach

Oak Ridge National

Laboratory

P.0. Box $X$

Oak Ridge, TN 37830

I. L. Brisbin, Jr.

Savannah River Ecology Laboratory

Aiken, SC 29801

H. C. Burkholder

Office of Nuclear Waste

Isolation

Battelle Memorial Institute

$505 \mathrm{King}$ Avenue

Columbus, $\mathrm{OH} 43201$

T. E. Hakonson

Los Alamos Scientific Laboratory

P.0. Box 1663

Los Alamos, NM 86544

M. Smith, Director

Savannah River Ecology

Laboratory

Drawer E

Aiken, SC 29801

J. J. Davis

Off ice of Nuclear

Regulatory Research

U.S. Nuclear Regulatory Commission

Washington, D.C. 20545 
F. W. Whicker

Radiology and Radiation

Biology Department

Colorado State University

Fort Collins, CO 80521

A. F. Perge

Office of Nuclear Waste

Management

Washington, DC 20545

(8) DOE Office of Health and

Environmental Research

Washington, DC 20545

N. F. Barr

W. W. Burr

C. E. Carter

R. C. Dah Iman

R. E. Franklin

W. S. Osburn

J. Swinebroad

R. L. Watters

\section{ONSITE}

UNC Nuclear Industries

T. E. Dabrowski

Hanford Engineering Development Laboratory

G. D. Carpenter

(10) DOE - Richland Operations

J. C. Cummings

0 . J. Elgert/J. L. Rhoades

R. E. Gerton

B. R. Goranson

H. E. Ransom $/ F$. Aust in

M. W. Shupe

F. R. Standerfer/P. G. Harris

M. W. Tiernan/D. R. Elle

M. G. White/P. F. Dunigan

M. J. Zamorsk $i$
(30) Rockwell Hanford Operations

H. Babad

D. J. Brown

L. E. Bruns

J. L. Deichman

R. D. Fox

R. J. Gimera

M. K. Harmon

W. F. Heine

R. E. Isaacson

J. E. Kinser

C. W. Manry

D. A. Marsh

H. E. McGuire

L. P. McRae

R. M. Mitche 11 (10)

G. C. Owens

D. Paine

J. V. Panesko

J. H. Roecker

J. A. Swenson

D. D. Wodrich

(34) Pacific Northwest Laboratory

W. J. Bair

L. L. Cadwe 11

B. W. Compton (3)

C. H. Connally

J. J. Fuquay

W. H. Rickard

L. E. Rogers (15)

R. G. Schreckhise

W. L. Temp leton

B. E. Vaughan

W. R. Wiley

Technical information (5)

Publishing Coordination (2) 